\title{
Hele tekster versus utdrag - hvilke tekster velger norsklærerne?
}

\author{
Sigrid Skaug og Marte Blikstad-Balas ${ }^{\star}$ \\ Universitetet $i$ Oslo
}

\begin{abstract}
Sammendrag
Lesing av skjønnlitteratur er en sentral del av norskfaget. Med innføringen av K06 ble listene over verk og forfatterskap fjernet fra norskplanen, og valg av tekster ble med dette opp til den enkelte lærer - et prinsipp som videreføres i fagfornyelsen 2020 . Vi vet lite om hvilke tekster lærere velger å bruke i norskundervisningen, og i hvilken grad de leser hele teksten eller et eller flere utdrag fra den, noe vi med denne studien ønsker å undersøke. Datamaterialet bygger på en spørreundersøkelse med 153 norsklærere i vg3, der vi kartlegger hvilke litterære utdrag og hele verk lærerne bruker i undervisningen og deres holdninger til lesing av utdrag og hele verk. Et tydelig funn er at utdrag er en svært utbredt praksis blant lærerne i utvalget. Analysen viser også at visse enkelttekster (hovedsakelig fra 1800-tallet) og utvalgte deler av Henrik Ibsens forfatterskap og tekster er så hyppig brukt i undervisningen på tvers av klasser, at denne litteraturen i praksis er med på å opprettholde en form for skjult litterær kanon. Videre viser analysen at lærerne oppfatter lesing av utdrag og hele verk som to svært forskjellige aktiviteter, som tjener relativt motsetningsfylte mål i norskfaget.
\end{abstract}

\section{Norsk: Skjønnlitteratur; lesing; utdrag; kanon; norskfaget}

\begin{abstract}
Reading of literature plays a key role in the language arts subject. In Norway, the curriculum has since 2006 given teachers' ample room to decide themselves which authors and which literary texts they want to use in their classrooms. To investigate what texts they actually choose to include in their teaching and whether the texts are complete literary works or excerpts, was the main aim of the present study. Drawing on a survey with 153 language arts teachers from the last year of upper secondary school, we have mapped what literary texts and excerpts teachers report reading in class, and teachers' perceptions of using complete texts versus excerpts. A key finding is that a majority of the teachers report extensive use of literary excerpts, and that some texts (mainly from the 1800s) and parts of Henrik Ibsen's works predominate across classrooms. The study also suggests that teachers view the reading of excerpts and complete texts as two distinct activities that often serve contradictory purposes.
\end{abstract}

Keywords: Literature; reading; excerpts of literary texts; Norwegian language arts

Received: January, 2019; Accepted: May, 2019; Published: July, 2019

\footnotetext{
^Korrespondanse: Marte Blikstad-Balas, Universitetet i Oslo, Postboks1099, Blidern, 0317 Oslo, epost: marte.blikstad-balas@ils.uio.no
}

(C) 2019 Sigrid Skaug og Marte Blikstad-Balas. This is an Open Access article distributed under the terms of the Creative Commons Attribution 4.0 International License (https://creativecommons.org/licenses/by-nc/4.0/), allowing third parties to copy and redistribute the material in any medium or format and to remix, transform, and build upon the material for any purpose, even commercially, provided the original work is properly cited and states its license. Citation: Sigrid Skaug og Marte Blikstad-Balas. "Hele tekster versus utdrag - hvilke tekster velger norsklarerne?” Nordic fournal of Literacy Research, Vol 5(1), 2019, pp. 85-117. http://dx.doi.org/10.23865/njlr.v5.1566 


\section{S. Skaug og M. Blikstad-Balas}

\section{Introduksjon}

Lesing av skjønnlitteratur og litteraturundervisning har vært en sentral del av norskfaget i det meste av det 20. århundre, men skjønnlitteraturens plass er ikke lenger like udiskutabel som før (Hamre, 2014; Smidt, 2018). Som Kjelen (2018) understreker, er ordet litteratur nesten fraværende i læreplanene siden 2006, der han finner det han omtaler som "et tekstfag». Det er til stadighet debatt om hva slags norskfag vi har og bør ha - og svært ofte ender slike debatter i et spørsmål om litteraturens rolle i faget og ikke minst hvilke tekster elever bør møte i skolens klart største fag (Eyde \& Skovholt, 2017; Fodstad, 2017). Ofte koker det hele ned til et spørsmål om danning eller nytte, som historisk sett har vært de to måtene å begrunne skolens fag på (Aase, 2005). Hvilken rolle litteraturen kan ha innenfor dannelsesfaget eller nyttefaget norsk, blir således et viktig spørsmål.

Pål Hamre (2014) gir en historisk fremstilling av hvordan lesing av skjønnlitteratur har blitt legitimert som en del av norskfaget siden 1739 og frem til i dag. Han poengterer at norskfagets identitet har svingt frem og tilbake mellom de nytte- og dannelsesorienterte sidene ved faget. 2000-tallet kjennetegnes av reformer som har styrket de nytteorienterte sidene ved norskfaget, noe som kan ha gått på bekostning av og nedtonet de dannelsesorienterte sidene ved faget. Dette kom særlig til uttrykk med Kunnskapsløftet og innføringen av de grunnleggende ferdighetene i 2006, som medførte et forsterket fokus på testing av elevenes prestasjoner (Berge, 2012; Hamre, 2014). Parallelt med dette økte fokuset på ferdigheter, er det fremdeles dannelse som står sterkest i beskrivelsen av de overordnede formålene med norskfaget fra K06 (Rogne, 2008). For eksempel beskrives norsk som et sentralt fag for «kulturforståelse, kommunikasjon, dannelse og identitetsutvikling»(Kunnskapsdepartementet, 2013, s. 1).

Et sentralt tema i diskusjoner om litteraturens plass i skolen, er at vi ikke lenger har noen uttalt kanon og at det dermed i prinsippet er opp til hver enkelt lærer å bestemme hva som skal leses og hvordan. De som argumenterer for en kanon argumenterer ofte med at alle barn i skolen skal få tilgang til kulturell kapital og fellesskap. Den overordnede delen av læreplanen understreker nettopp det å gi tilgang til felles referanserammer - og det å lese felles litteratur kan selvsagt sees på som relevant i arbeidet med dette. Men kanon er ikke eneste vei å gå for dem som er opptatt av historien og historiene vi er en del av (Smidt, 2018). Det er heller ikke gitt at det ikke blir lest felles litteratur bare fordi lærerne ikke har noen felles statlig liste de må forholde seg til - og motsatt er det ikke gitt at enkelte tekster ikke leses bare fordi de ikke (lenger) står listet opp i en læreplan. Bente Aamotsbakken (2011) hevder at noen forfattere og tekster ser ut til å være kanonisert nesten uavhengig av læreplanene, gjennom tekstutvalg i lærebøkene og deres tekstsamlinger. Nyere lærebøker viderefører altså den etablerte kanon gjennom sitt utvalg av tekster. Aamotsbakken (2011) påpeker at dersom det viser seg at formuleringene i dagens læreplan ikke har så stor innflytelse på lærebøkenes tekstutvalg og hva som leses i klasserommet, vil kanonisert litteratur trolig fortsatt bli mye lest. 
Et norskdidaktisk problem i en tid der det blitt fremsatt en rekke påstander om hva elever i norsk skole leser og ikke leser, og hva de burde lese, er at vi egentlig ikke har nok kunnskap om hva elevene faktisk leser og hvordan dette arbeidet rammes inn, noe også Aamotsbakken (2011) etterlyser. Til tross for at det finnes en rekke casestudier av arbeid med litteratur og flere solide analyser av læreverk i norsk, er det få studier som har undersøkt hvilke tekster lærerne på tvers av mange klasserom velger å bruke og hvordan de begrunner disse valgene. I vår studie har vi derfor gjennomført en spørreundersøkelse med norsklærere i vg3, der vi forsøker å kartlegge to forhold knyttet til lesing av litteratur:

i. Hvilke skjønnlittercere utdrag og hele verk velger et utvalg norsklerere for litteraturundervisning $i$ vg 3 ?

ii. Hva er lerernes holdninger til lesing av skjønnlittercere utdrag og hele verk?

Vi har brukt både flervalgsvar og åpne spørsmål for å undersøke hva lærerne bruker av litteratur og hvordan de jobber med både utdrag og litterære verk. Grunnen til at vi er spesielt opptatt av utdrag, er at flere har problematisert en økende tendens til å vise frem utdrag av verk fremfor hele verket (se f.eks. Aamotsbakken, 2018; Penne, 2010). Vi synes det er viktig å belyse ikke bare hva slags litteratur lærerne sier de bruker i undervisningen, men også hva de oppfatter som formålet med å lese for eksempel en hel roman kontra et utdrag av et skuespill.

\section{Litteraturens rolle i norskfaget}

Det finnes en rekke gode grunner til at elever bør møte litteratur i morsmålsfaget, knyttet til både nytte og danning. En helt sentral begrunnelse for å arbeide med litteratur i skolen er knyttet til at vi gjennom litteratur får tilgang til andre menneskers tanker, opplevelser og perspektiver. Dette argumentet kan spores tilbake til Martha Nussbaum (2010). Hun hevder at elever ikke bare bør utvikle logikk og kunnskap om samfunnsforhold for å kunne forholde seg til den komplekse verden vi lever i, men at det også er nødvendig å utvikle evnen til å leve seg inn i andres liv for. Denne evnen kaller hun "the narrative imagination" (Nussbaum, 2010, s. 95). Skjønnlitteratur bidrar ifølge Nussbaum til å utvikle en narrativ forestillingsevne, da den giør det mulig å forstå det fremmede gjennom at leseren lever seg inn i andre kulturer og andre menneskers tanker og handlinger. Narrativ forestillingsevne dreier seg om å kunne sette seg inn i forskjellige fiktive karakterers historier, å kunne se verden gjennom deres øyne og å forstå deres følelser og ønsker. Det er spesielt dramaet og romanen Nussbaum (1997) fremhever som sentrale sjangre for å trene elevene i å utvikle den narrative forestillingsevnen. Hun understreker at det ikke er nok å føle med en romankarakter, da dette kun kan være et tegn på medmenneskelighet. Det er avgjørende at litteraturen skal forstyrre oss. Læreren må derfor tenke over at verkene som blir tatt inn i klasserommet skal utfordre konvensjonelle sannheter og verdier, og la leseren møte mennesker man stort sett helt vil unngå å møte (Nussbaum, 1997). 
Tilgang til en annens perspektiv gjennom litteratur kan være en øvelse i empati og innsikt $\mathrm{i}$ andre menneskers sinn, og har betydning for moralsk samhandling (Nussbaum, 1997, 2010). Skolen bør ifølge Nussbaum (2010) utvikle elevenes evne til å se verden fra andre menneskers perspektiv, og særlig fra de samfunnet betrakter som mindreverdige. Arbeid med litteratur står i en særstilling for å fremme dette - og Nussbaum $(1997,2010)$ hevder at litteraturarbeid er avgjørende for å forme elever til verdensborgere med et empatisk syn på ulike mennesker og kulturer som er forskjellig fra leseren selv.

Et stort spørsmål som stadig er oppe til debatt, er hvilke konkrete tekster som skal leses i norskfaget. Svaret fremkommer som kjent ikke eksplisitt i læreplanen for Kunnskapsløftet, heller ikke etter fagfornyelsen som trer i kraft i 2020. Dette gir stor frihet til den enkelte lærer, men det er likevel ikke helt fritt frem å lage sitt eget litteraturfag. Skolens styringsdokumenter legger føringer for arbeidet i skolen, og dermed også litteraturundervisningen.

Ifølge formålsparagrafen i Opplæringslova (1998), skal opplæringa blant annet «[...] bidra til å utvide kjennskapen til og forståinga av den nasjonale kulturarven og vår felles internasjonale kulturtradisjon» (\$ 1-1). Atle Skaftun og Per Arne Michelsen (2017) omtaler dette som den overordnede begrunnelsen for litteraturundervisning i skolen. Den nye overordnede delen av læreplanen, som utdyper formålsparagrafen, sier ikke noe spesifikt om litteratur i norskfaget. Likevel berører mange av formuleringene arbeidet med litteratur. I likhet med formålsparagrafen, blir viktigheten av å formidle kunnskap om både vår egen og andres kultur presisert - og det å gi tilgang til den nasjonale kulturarven fremheves som en viktig del av skolens mandat (Utdanningsdirektoratet, 2018). Lesing av norsk og internasjonal litteratur kan, i lys av Nussbaums teori om den narrative forestillingsevne, bidra til å forstå vår egen og andres kulturer. Et slikt aspekt ved norskfaget som kulturell døråpner finner vi også i det vedtatte kjerneelementet tekst i kontekst, hvor vi kan lese at elevene gjennom norskfaget skal «lese tekster for å få estetiske opplevelser, bli engasjert, undre seg, lære og få innsikt i andre menneskers tanker og livsbetingelser» (Kunnskapsdepartementet, 2018, s. 9). Gjennom disse formuleringene kan man se på norskfaget ut fra et danningsperspektiv, som dreier seg om å utvikle elevenes tanker om verden og seg selv (Aase, 2005).

\section{Tidligere forskning på lesning av skjønnlitteratur i skolen}

Karianne Rødnes (2014) har sammenfattet skandinavisk forskning på litteratur og finner at de to tradisjonene som primært har gjort seg gjeldende i ungdomsskole og videregående skole i Norge, er erfaringsbaserte og analytiske tilnærminger til litterære tekster. De erfaringsbaserte tilnærmingene, der elevene skaper mening i teksten gjennom en personlig inngang, viser seg å skape engasjement hos elevene. Alene kan dette imidlertid gjøre det vanskelig for elevene å se det faglige innholdet i undervisningen, noe som skaper et behov for mer analytiske innganger. Dette kan blant annet gjøres gjennom å lære elevene et metaspråk til å snakke om tekst, finne språklige virkemidler 
i teksten og litteraturhistorisk tilknytning. Studier antyder at vekt på litteraturhistorie og kunnskap om tekst gjør at elevene ikke opplever at litteraturen berører dem, og at arbeidet med litteraturen blir lite motiverende for mange. Videre påpeker Rødnes (2014) at det må bli gjort tydelig for elevene at målet ikke er å søke en forståelse som sammenfaller med lærerens eller lærebokas forståelse av teksten. En analytisk inngang må ikke ses ensbetydende med å søke etter en kanonisert tolkning og vektlegging av litteraturhistorisk kunnskap, men handler også om å forankre tolkningene tydeligere i teksten og utvikling av et språk til å snakke om tekst.

Når det gjelder spørsmålet om hva som leses, er det i prinsippet opp til hver enkelt lærer å velge hva slags litteratur de ønsker å bruke i litteraturundervisningen. Som nevnt innledningsvis kan det se ut til at det likevel finnes en skjult kanon gjennom lærebøkenes utvalg av tekster (Aamotsbakken, 2011, 2018). I tillegg er det flere norske studier som finner at litterære utdrag har hatt en sentral plass i norskfagets lærebøker gjennom tidene, og at lesebøker historisk sett har vært utbredt i norskfaget både i den obligatoriske skolen og i videregående skole (Penne, 2012; Skjelbred et al., 2017).

En omfattende videostudie, Linking Instruction and Student Achievement -LISA (Klette, Blikstad-Balas \& Roe, 2017) som har filmet 178 timer med norskundervisning fra 47 ulike klasserom på åttende trinn, viser at det leses få hele litterære verk som del av undervisningen (Gabrielsen, Blikstad-Balas og Tengberg, til fagfellevurdering). Omtrent alt som leses er tekster fra læreboka, og når det gjelder romaner, er det utdrag som dominerer. Kun én av de 47 ulike åttendeklassene leste en felles bok i løpet av uken de ble observert. I den grad elevene leser hele romaner, dreier dette seg om selvvalgte bøker som leses individuelt, og som i liten grad blir en del av felles undervisning. Lærerne gir sjelden noen begrunnelse for hvorfor elevene skal lese, og dersom elevene skal presentere eller skrive om det de har lest, så ligger fokuset på gjengivelse av handling og fakta om forfatter, ikke på tolkning, refleksjon eller analyse.

Forskning på bruk av litteratur i skolen antyder at litteraturen ofte ikke er målet i seg selv, men at litteraturen ofte brukes for å illustrere eller eksemplifisere litterære epoker eller bestemte sjangertrekk som del av skriveundervisning (Gabrielsen, Blikstad-Balas \& Tengberg, til fagfellevurdering; Penne, 2012; Schüllerquist, 2008). Ifølge Penne (2010) har litteraturen langt på vei blitt et middel for å tjene andre av skolens mål, der elevene bruker litteratur for å illustrere og utdype tema de arbeider med i andre sammenhenger enn litteraturundervisningen. Følgen av å bruke litteratur som faglig supplement for å illustrere for eksempel en historisk epoke blir at litteraturen fremstilles som «sannhet», og ikke fiksjon, noe som kan føre til at elevene får problemer med å skille mellom fakta og fiksjon (Hærgard \& Engh, 2013; Penne, 2013).

\section{Forskningsdesign}

Vi har utviklet et spørreskjema der vi stiller spørsmål om hvilke tekster (romaner, noveller og drama) lærerne bruker i sin undervisning, samt holdningene deres knyttet 
til lesing av utdrag kontra hele verk. Undersøkelsen består i hovedsak av lukkede spørsmål med likert-skala med fem trinn der lærerne skal vurdere i hvor stor grad de er enige i ulike påstander om litteratur i undervisningen. I tillegg inneholder spørreskjemaet noen åpne spørsmål der lærerne kan skrive inn svar selv (for eksempel blir de bedt om å liste opp både hele verk og utdrag de vanligvis jobber med i klassene sine på vg3). Hele spørreskjemaet ligger vedlagt (vedlegg 1 ).

\section{Datainnhenting}

Artikkelens førsteforfatter har hatt ansvar for all datainnhenting, og sørget for at undersøkelsen ble sendt ut til potensielle respondenter per epost, det vil si norsklærere i videregående skole som underviser på vg3, enten på påbygg eller studiespesialiserende utdanningsprogram. I invitasjonen på e-post fulgte det med en lenke til websiden der det anonyme spørreskjemaet skulle fylles ut, noe som er den vanligste fremgangsmåten for bruk av digitale spørreskjemaer (Fowler, 2009). En fordel med digitale skjema, er at det muliggjør et større utvalg, og gir muligheten til å innhente informasjon fra et større geografisk område enn for eksempel personlig overlevering av spørreskjemaet på papir. I tillegg vil terskelen for å gjennomføre undersøkelsen trolig være lavere enn hvis skjemaet skulle blitt sendt per post (Cohen et al., 2011).

\section{Utvalg}

For å komme i kontakt med aktuelle lærere har forfatterne benyttet egne norskdidaktiske nettverk. Også ulike norskdidaktiske sider på Facebook ble tatt i bruk, der aktuelle lærere kunne melde sin interesse. En fordel ved å bruke sosiale medier til rekruttering er at de aktuelle lærergruppene på Facebook består av til sammen flere tusen norsklærere på ulike trinn, så vi kunne nå ut til mange aktører samtidig. I tillegg antok vi at norsklærergruppene representerer et bredt geografisk område med lærere i ulike aldre og med ulik lærererfaring. En problematisk side ved denne utvalgsmetoden er at vi kun nådde ut til norsklærere som er medlemmer av Facebooks nettverk eller som kunne nås gjennom de norskdidaktiske nettverkene forfatterne hadde tilgang til. Derfor ble alle som meldte sin interesse også oppfordret til å spre ordet dersom de kjente andre lærere som de trodde kunne være aktuelle respondenter, såkalt snøballutvelging (Cohen et al., 2011). Etter hvert som respondentene meldte seg, oppdaget vi at det store flertallet av lærere var fra Hedmark, Oslo og Akershus. Artikkelens førsteforfatter sende da ut forespørsler til rektorer og avdelingsledere i alle landets fylker, for slik å kunne oppnå et noe mer representativt utvalg. Dette bedret fordelingen på ulike fylker betraktelig, og vi endte opp med et utvalg der alle landets fylkes er representert. Av de 219 som fikk tilsendt invitasjoner etter å ha meldt sin interesse var det 153 som besvarte undersøkelsen. Det er en spredning i ulike fylker respondentene er ansatt $i$, både kvinner og menn er representert $i$ undersøkelsen og både erfarne lærere og relativ nyutdannede lærere har deltatt (se vedlegg 2 for tabelloversikt over respondentenes bakgrunnsvariabler). 


\section{Analyse}

Analysene av de lukkede spørsmålene består primært av å kartlegge frekvenser og fordelingen på hvert spørsmål, det en kan kalle en deskriptiv analyse der målet er å identifisere og beskrive mønstre (Creswell, 2014). De åpne spørsmålene ble analysert gjennom innholdsanalyse, der dataprogrammet NVivo ble brukt for å systematisere analysearbeidet (Hsieh \& Shannon, 2005). Første fase i analysearbeidet besto av å lese gjennom alle fritekstsvarene flere ganger for å oppnå en helhetsforståelse. Deretter ble svarene lest ord for ord, for å utforme koder som bygger på respondentenes formuleringer, før de tekstnære kodene ble sortert i større tematiske kategorier (Hsieh \& Shannon, 2005). Målet med en slik prosess var å lage kategorier som grupperer de svarene som er analytisk like og skille mellom svarene som er ulike (Fowler, 2009). Deretter besto analysen av å undersøke hvor mange respondentsvar det er i hver kategori, for slik å identifisere tendenser i tekstsvarene. Gjennom en survey som både har pre-definerte kategorier og flervalgsalternativer, åpner vi både for en systematisk oversikt over hvordan respondentene svarer på de samme spørsmålene, og for at lærerne selv formulerer det de vil si om litteraturundervisningen sin med egne begreper.

\section{Funn}

Et mål med denne undersøkelsen er å finne ut mer om hva lærerne velger å lese i norskfaget på vg3, og hva slags fordeling de har mellom lesing av utdrag og hele verk. Totalt nevner respondentene 179 ulike verktitler på utdrag og 93 verktitler på hele verk innen sjangrene romaner, noveller og drama (se vedlegg 3 og 4). Det er imidlertid grunn til å anta at lærerne ikke har skrevet ned absolutt alle utdrag og hele verk de bruker i undervisningen sin. Vi ser at noen har skrevet lange og utfyllende lister, mens andre kun nevner noen eksempler på verktitler, forfatternavn eller tidsperioder de leser utdrag eller hele verk fra i sin undervisning. Likevel ser det ut til at relativt mange av verkene som leses er særegne fra klasse til klasse, da en stor andel av titlene på utdrag (49 \%) og hele verk (57\%) kun oppgis av én lærer. Eksempler på slike verk er utdrag fra romanen Sterk sult, plutselig kvalme (Trude Marstein, 1998) og novellen Kruttrøyk (Torborg Nedreaas, 1945) som oppgis at leses i sin helhet. Dette indikerer at lærerne i stor grad benytter seg av valgfriheten i K06 når det gjelder valg av litterære verk. Denne valgfriheten er også noe lærerne i utvalget ser ut til å ønske at skal bevares, da 75 \% av lærerne oppgir at de er uenig eller helt uenig i påstanden om at de skulle ønske det var fastsatt i læreplanen hvilke litterære verk som skal brukes i undervisningen.

\section{Lesing av utdrag}

Et viktig funn er at lesing av skjønnlitterære utdrag er en svært utbredt praksis blant lærerne som deltok i vår studie. Ikke bare har lærerne listet opp en rekke ulike utdrag av både romaner, noveller og drama, men $84 \%$ av de 153 lærerne oppgir at de bruker mer utdrag enn hele verk i sin undervisning. Tabell 1 gir en oversikt over de fem mest leste utdragene, av de 179 oppgitte titlene på utdrag, fordelt etter sjangerkategori. Det 
er særlig fire romaner som skiller seg ut hvis vi ser på verkene som oppgis i romansjangeren. Sult (Knut Hamsun, 1890) nevnes av flest lærere, der til sammen 96 stykker oppgir at de leser utdrag fra dette verket. Så kommer Amtmannens døtre (Camilla Collett, 1855), Kristin Lavransdatter - én av de tre romanene i trilogien (Sigrid Undset, 1920-1922) og Albertine (Christian Krogh, 1886), som nevnes av henholdsvis 64, 61 og 59 av lærerne i utvalget. Deretter er det et relativt stort i hopp i antall lærere som nevner de øvrige romanene, da disse nevnes av mellom en til 33 lærere.

Det er to verk som skiller seg ut blant novellene lærerne oppgir at de leser utdrag fra. Som Tabell 1 viser blir både Karens jul (Amalie Skram, 1885) og Karen (Alexander Kielland, 1882) nevnt av 16 lærere. Tolv av disse har oppgitt at de leser utdrag fra både Karens jul og Karen, mens åtte av lærerne nevner ett av verkene. Videre oppgir de 153 lærerne flere ulike drama som de leser utdrag fra. Som tabellen viser er samtlige av de fem mest leste dramaene skrevet av Henrik Ibsen. Her skiller Et dukkehjem (1879) seg markant ut, da dette verket nevnes av 47 av lærerne i utvalget, som utgjør nesten en tredjedel av alle lærerne. De øvrige dramaene på topp fem nevnes av mellom åtte og 19 lærere.

Tabell 1. Oversikt over de fem mest frekvente utdragene fordelt etter sjanger.

\begin{tabular}{|l|r|r|}
\hline Verk & Utgitt & Frekvens \\
\hline Utdrag fra romaner & & 1890 \\
\hline Sult (Knut Hamsun) & 1855 & 96 \\
\hline Amtmandens Døtre (Camilla Collet) & 1886 & 64 \\
\hline Kristin Lavransdatter - én av dem (Sigrid Undset) & $1920-1922$ & 61 \\
\hline Albertine (Christian Krogh) & $2009-2011$ & 59 \\
\hline Min Kamp - én av dem (Karl Ove Knausgård) & & 33 \\
\hline Utdrag fra noveller & 1885 & 16 \\
\hline Karens jul (Amalie Skram) & 1882 & 16 \\
\hline Karen (Alexander Kielland) & 1879 & 8 \\
\hline Ballstemning (Alexander Kielland) & 1945 & 5 \\
\hline Kruttrøyk (Torborg Nedreaas) & 1899 & 4 \\
\hline Det røde gardin (Amalie Skram) & & 47 \\
\hline Utdrag fra drama & 1879 & 19 \\
\hline Et dukkehjem (Henrik Ibsen) & 1881 & 14 \\
\hline Gengangere (Henrik Ibsen) & 1882 & 12 \\
\hline En folkefiende (Henrik Ibsen) & 1867 & 8 \\
\hline Peer Gynt (Henrik Ibsen) & 1884 & \\
\hline Vildanden (Henrik Ibsen) & & \\
\hline
\end{tabular}

Våre funn tyder også på at læreboka i stor grad er styrende for hvilke tekstutdrag lærerne velger å bruke i undervisningen. $71 \%$ av lærerne oppgir at de ofte eller alltid henter utdragene fra læreboka eller lærebokas tekstsamling, og $32 \%$ oppgir at de ofte henter utdrag fra andre lærebøker enn den klassen bruker. Dette betyr at når lærerne går "ut av læreboka» på jakt etter litteratur, er det faktisk ofte en annen lærebok de går til. Kun $12 \%$ av lærerne oppgir at de sjelden eller aldri henter utdragene fra klassens lærebok eller andre lærebøker. Til sammenlikning er det relativt få 
respondenter som oppgir at de lager utdragene selv fra originalteksten, der $20 \%$ sier at de ofte gjør det og $44 \%$ sier at de noen ganger gjør det.

\section{Lesing av hele verk}

Tabell 2 gir en oversikt over de fem mest leste hele verkene, av de til sammen 93 titlene som blir oppgitt, fordelt etter sjangerkategorier. De tre mest leste romanene er Bli hvis du kan. Reis hvis du må (Helga Flatland, 2010), Pan (Knut Hamsun, 1894) og Sult (Knut Hamsun, 1890), som nevnes av henholdsvis elleve, ti og ni lærere. Ettersom det er relativt få som nevner disse verkene, har vi kontrollert for hvilke fylker lærerne er ansatt i, da en overrepresentasjon av ett fylke kan være en følge av at lærerne jobber ved samme skole og av den grunn leser det samme verket. Vi finner imidlertid at lærerne som oppgir de tre mest leste romanene er spredt på ulike fylker. Det er to av verkene innenfor novellesjangeren som skiller seg ut hvis man ser på hvor mange lærere som nevner disse. Det er de samme to novellene som er mest frekvente for lesing av hele verk, som for lesing av utdrag, Karens jul (Amalie Skram, 1885) og Karen (Alexander Kielland, 1882). Henholdsvis 13 og tolv lærere oppgir at de leser dem i sin helhet, og i likhet med de som bruker utdrag fra disse novellene, oppgir et flertall av lærerne (10) at de leser begge. Vi finner også her en spredning i fylker lærerne er ansatt i.

Blant de dramatiske verkene som leses i sin helhet, er det fire tekster som skiller seg klart ut når det gjelder hvor hyppig verktitlene oppgis. Samtlige av de fire mest leste dramaene som leses i sin helhet, i likhet med utdragene, er skrevet av Henrik Ibsen. Dette gjelder Gengangere (1881), En folkefiende (1882), Et Dukkehjem (1879) og Vildanden (1867), som nevnes av mellom 38 og 20 lærere. Deretter er det et

Tabell 2. Oversikt over de fem mest frekvente hele verkene fordelt etter sjanger.

\begin{tabular}{|l|r|r|}
\hline Verk & Utgitt & Frekvens \\
\hline Romaner & & 11 \\
\hline Bli hvis du kan. Reis hvis du må (Helga Flatland) & 2010 & 10 \\
\hline Pan (Knut Hamsun) & 1894 & 9 \\
\hline Sult (Knut Hamsun) & 1890 & 7 \\
\hline Victoria (Knut Hamsun) & 1898 & 7 \\
\hline Sjur Gabriel (Amalie Skram) & 1887 & 13 \\
\hline Noveller & & 12 \\
\hline Karens jul (Amalie Skram) & 1885 & 4 \\
\hline Karen (Alexander Kielland) & 1882 & 4 \\
\hline Faderen (Bjørnstjerne Bjørnson) & 1860 & 3 \\
\hline En god samvittighet (Alexander Kielland) & 1880 & 38 \\
\hline Luren (Mauritz Hansen) & 1819 & 26 \\
\hline Drama & & 25 \\
\hline Gengangere (Henrik Ibsen) & 1881 & 20 \\
\hline En folkefiende (Henrik Ibsen) & 1882 & 7 \\
\hline Et dukkehjem (Henrik Ibsen) & 1879 & 1884 \\
\hline Vildanden (Henrik Ibsen) & 1867 & \\
\hline Peer Gynt (Henrik Ibsen) & & \\
\hline
\end{tabular}


hopp ned til det femte mest leste dramatiske verket, som nevnes av sju lærere, som for øvrig også er skrevet av Henrik Ibsen. Ibsen ser altså ut til å ha en sentral plass i lærernes undervisning, både når det gjelder lesing av utdrag og hele verk. Denne tendensen er også tydelig om vi ser på svarene til lærere som oppir forfatternavn uten å spesifisere tittel på hvilke hele verk de leser. Her er Henrik Ibsen den mest nevnte forfatteren, der 28 av lærerne har svar av typen: «Et drama av Ibsen [...]» (lærer 49, spm. 7) og «Et Ibsen-skuespill - varierer fra år til år [...]» (lærer 127, spm. 7). Til sammenlikning blir de øvrige åtte forfatternavnene som blir nevnt, oppgitt av mellom en og to lærere.

Våre funn tyder på det leses flest hele verk fra dramasjangeren, mens når det gjelder utdragslesing er det en klar overvekt fra romaner. Til sammen oppgir lærerne 51 ulike romaner, 29 ulike noveller og 13 ulike drama som leses i sin helhet. Selv om lærerne oppgir betydelig færre ulike titler på dramatiske verk, er det dramatiske tekster som blir hyppigst nevnt at leses i sin helhet. De dramatiske tekstene blir oppgitt totalt 164 ganger, romanene blir nevnt 123 ganger og novellene 64 ganger. Når det kommer til lesing av utdrag, blir titler på romaner nevnt betydelig flere ganger enn titler på noveller og drama. De 117 ulike romantitlene det leses utdrag fra blir til sammen nevnt 767 ganger, fordi mange leser utdrag fra de samme verkene. Til sammenlikning blir de 20 ulike dramatiske tekstene det leses utdrag fra nevnt 135 ganger, og de 42 ulike novellene blir nevnt 110 ganger. Dette betyr altså at lærerne virker å være mer enige om hvilke romanutdrag de skal lese enn utdrag fra drama og noveller. Likevel virker lærerne å være enige i at det er Ibsens forfatterskap det skal leses dramatiske verk fra, både når det gjelder utdragslesing og lesing av verk i sin helhet.

\section{Tekster fra 1800-tallet blir hyppigst lest}

Tekstene som lærerne oppgir at de bruker i undervisningen sin, både når det gjelder utdrag og hele verk, varierer fra relativt gamle tekster til nyere litteratur. Ved å se nærmere på når de ulike verkene er utgitt kan man se klare tendenser til at visse tidsperioder er sterkere representert enn andre.

Verkene som lærerne oppgir at de leser utdrag fra, varierer mellom eldre tekster fra 1300-tallet til nyere tekster fra 2000-tallet. Her nevnes eksempelvis novellesamlinga Dekameronen (Giovanni Boccacio, 1348-1353) og samtidsromanen Alle utlendinger har lukka gardiner (Maria Navarro Skaranger, 2015). Dersom man ser på hvilke århundrer utdragene er utgitt og undersøker hvilke tidsperioder det hyppigst leses utdrag fra, ligger hovedtyngden klart på 1800-tallet. Verk fra dette århundret blir til sammen nevnt 508 ganger. Til sammenlikning blir verk fra 1900-tallet, som nevnes nest flest ganger, oppgitt 332 ganger.

Det eldste verket som blir oppgitt at leses i sin helhet er dramaet Antigone (Sofokles), som ble nedskrevet omkring år $442 \mathrm{f} . \mathrm{Kr}$. De øvrige tekstene fordeler seg mellom 1700- og 2000-tallet, der Malin Persson Giolitos roman, Størst av alt (2017), er det nyeste verket. I likhet med tekstutdragene, er det verk fra 1800-tallet 
som blir hyppigst lest. Til sammen nevnes verk som leses i sin helhet fra dette århundret 219 ganger. Dette skiller seg klart fra verk fra 1900-tallet, som også her blir nevnt nest flest ganger, som til sammen nevnes 61 ganger. Det vil si at verk fra 1800-tallet klart blir hyppigst lest både når det gjelder utdragslesing og lesing av hele verk.

\section{Utdrag og hele verk tjener ulike mål}

En gjenganger i den delen av undersøkelsen som prøver å kartlegge holdninger og forklaringer til lærernes arbeid med litteratur, er at lærerne oppfatter det å lese utdrag og det å lese hele verk som to svært forskjellige aktiviteter, som tjener ulike mål i undervisningen. Lærerne uttaler seg gjennomgående langt mer positivt til det å lese hele verk, og mer problematiserende til det å lese utdrag. Dette giør lærernes begrunnelser for å lese såpass mange utdrag interessant.

For det første ser vi en tendens til at flere av lærerne omtaler utdrag som et fragmentert arbeid der man mister sammenhengen, mens arbeid med hele verk gir mulighet til å se helhet og sammenheng. 35 ulike lærere omtaler arbeid med utdrag som kan kategoriseres som «fragmentert». Utdrag beskrives som kun å gi et lite innblikk i en del av teksten eller at det er vanskelig å se sammenhengen og helheten. For eksempel skriver en lærer dette:

Utdrag og hele verk har ulik funksjon. Utdrag kan gi innblikk. Det er nesten litt dårlig gjort å bruke utdrag fordi det er tekst tatt ut av sin sammenheng. Læreren kan fylle inn foran og bak, men det vil aldri bli det samme. (lærer 128, spm. 17)

I motsetning til fragmentarisk, blir arbeid med hele verk av flere lærere beskrevet som å gi et helhetlig bilde og bedre sammenheng. 24 lærere skriver eksplisitt at hele verk bidrar til helhet og sammenheng. Her forekommer svar av typen: «Hele verk: mer fokus på teksten som helhet. Karakterer, handling og miljø» (lærer 95, spm. 17) og «Et utdrag vil aldri gi leseren det samme som hele verket. En får se helheten og ikke bare delen» (lærer 108, spm. 17).

For det andre er forholdet mellom bredde og dybde et moment som opptar flere av lærerne i sammenlikningen mellom arbeid med utdrag og hele verk. Flere av lærerne gir uttrykk for at arbeid med utdrag gir en bredere oversikt ettersom man rekker å lese flere tekster. Her trekkes det blant annet frem at utdrag gir kjennskap til flere ulike verk og forfattere. Videre fremhever 40 lærere at utdrag egner seg til å illustrere eller eksemplifisere litteraturhistoriske perioder, og at dette gir et bredere bilde eller en bedre forståelse av de litterære epokene. For eksempel forekommer svar av typen «Elevene får større oversikt over ulike tekster og eksempler fra periodene» (lærer 9, spm. 17) og «Utdrag brukast mest for å illustrere ein epoke og gjev ikkje same mogelegheit til å forstå og reflektere» (lærer 112, spm. 17). Dette viser at forståelse av det litterære verket i seg selv ikke nødvendigvis er hovedformålet med lesing av utdrag, men heller at arbeid med utdrag er et middel for å oppnå forståelse for aspekter som ligger utenfor det litterære universet. 
Mens utdrag kobles til bredde og oversikt, blir arbeid med hele verk knyttet til muligheten til å gå i dybden. 20 av lærerne påpeker eksplisitt at bruk av hele verk muliggjør fordypning i verket, med uttalelser av denne typen: «Hele verk gir mer dybde og elevene opplever at de får tid til fordypning. Kan roe seg med lesingen» (lærer 90, spm. 17). En av lærerne uttrykker et ønske om å få bedre tid til å lese tekster i sin helhet for å kunne gå i dybden på litterær analyse og forstå konteksten. Flere funn støtter opp under ønsket om bedre tid til å lese tekster i sin helhet, da $84 \%$ av lærerne er enig eller helt enig $i$ at de skulle ønske det var mer tid til å lese hele verk. Videre er flertallet av lærerne, $82 \%$, enig eller helt enig $i$ at det er for liten tid til å lese hele verk i undervisningen, og $81 \%$ av lærerne er enig eller helt enig $i$ at dersom de hadde hatt bedre tid ville de lest flere hele verk.

En tredje tendens i materialet er at flere av lærerne uttrykker at utdrag og hele verk fører til ulik grad av forståelse for teksten det arbeides med. Arbeid med utdrag blir beskrevet som å føre til mindre eller manglende forståelse, mens arbeid med hele verk gjør at elevene får en bedre forståelse. Blant de elleve lærerne som nevner at arbeid med utdrag fører til mindre, liten eller ingen forståelse forekommer for eksempel svar som: «Eleven får bare en liten smakebit og ingen forståelse» (lærer 47, spm. 17). I motsetning til dette, blir arbeid med hele verk beskrevet som å gi bedre forståelse for teksten. Tendensen i svarene til de 20 lærerne som eksplisitt påpeker at hele verk gir bedre forståelse, er at arbeid med hele verk gir en helhetsforståelse for verket. Det nevnes også at hele verk gir bedre forståelse for handling, tematikk, virkemidler, forfatter og periode. En av lærerne skriver for eksempel: «Det å bruke tid på å lese noen hele verk og jobbe godt med dem, gir en helhetsforståelse og et møte med en tekst som er kvalitativt bedre faglig enn å møte mange utdrag» (lærer 2, spm. 17).

Det store flertallet, $73 \%$ av lærerne, uttrykker dessuten at de er enig eller helt enig i påstanden: «Jeg tror elevene mine oppnår en grundigere og bedre forståelse av å lese hele verk enn å lese utdrag». Videre oppgir $61 \%$ av lærerne at de er enig eller helt enig $i$ at lesing av utdrag giør det vanskeligere for elevene å få en helhetsforståelse av det de har lest. Et paradoksalt funn i datamaterialet er at $86 \%$ av lærerne oppgir at formålet med å lese utdrag ofte eller alltid er å analysere, tolke og/eller reflektere, men samtidig omtaler flere av respondentene arbeid med utdrag som fragmentert og at det fører til mindre forståelse for teksten. Paradokset ligger i om det er mulig å analysere, tolke eller reflektere over et tekstutdrag som mange av lærerne mener gir liten mening eller er vanskelig å forstå.

Analysen tyder også på at lærere oppfatter at elevenes forståelse for den fiktive verden og i hvilken grad elevene klarer å leve seg inn i verket, er forskjellig ved lesing av utdrag og hele verk. $67 \%$ av lærerne sier at de er enig eller helt enig i at lesing av utdrag giør det vanskeligere for elevene å sette seg inn i den fiktive verden til karakterene i teksten (for eksempel føle sinne eller medfølelse overfor noen av karakterene). Når det kommer til elevenes innlevelse i teksten er det relativt mange av lærerne, 
$59 \%$, som er enten helt uenig eller uenig i at elevene klarer å leve seg like mye inn i et utdrag som $i$ et helt litterært verk.

\section{Diskusjon}

Egentlig er det overraskende hvor lite systematisk kunnskap vi har om hva elever leser av litteratur (og sakprosa) i videregående skole. Vår studie er ikke noen heldekkende undersøkelse av hva som leses over hele landet, og den sier heller ikke mye om hvordan dette arbeidet skjer. Men den viser noen klare tendenser i hvordan en rekke lærere forholder seg til litteratur i norskfaget og hva de oppgir at de pleier å lese med sine vg3 klasser. De funnene vi vil fremheve i den kommende diskusjonen, handler om den utstrakte bruken av utdrag, de få enkelttekstene og forfatterne som går igjen i en rekke klasserom og den beskjedne andelen tekster fra elevenes samtid.Vi starter med et velkjent norskdidaktisk tema, nemlig utstrakt bruk av litterære utdrag.

Utdragenes sentrale posisjon i norskundervisningen, som en rekke norskdidaktikere har problematisert tidligere, ser ut til fortsatt å være gjeldende. Flertallet av lærerne $i$ vår undersøkelse oppgir at de bruker mest utdrag $i$ sin undervisning. Dette bekreftes også gjennom det faktum at lærerne oppgir langt flere titler på skjønnlitterære utdrag enn hele verk når de skal liste opp tekster de jobber med i løpet av vg3, og utdragene som oppgis blir nevnt av betydelig flere lærere enn verkene som oppgis at leses i sin helhet. De fleste utdrag vil alltid være representanter for noe større, noe elevene gjennom utdraget $\mathrm{i}$ beste fall får en liten bit av. Penne $(2006,2010,2012)$ er tydelig i sin kritikk av den utbredte bruken av utdrag i norsktimene, og understreker at lesing av utdrag gjør det vanskelig for elevene å oppnå en helhetlig forståelse av litteraturen. Bruken av utdrag antyder ofte en hermeneutisk utfordring, fordi samspillet mellom både del og helhet er avgjørende for å oppnå en meningsfull fortolkning og forståelse av tekst (se f.eks. Bruner, 1996; Gilje \& Grimen, 1993). At utdrag kun presenterer bruddstykker av tekstens helhet, er også noe respondentene i utvalget vårt problematiserer. Flere av lærerne omtaler arbeid med utdrag som fragmentarisk, man mister sammenhengen og helheten, og dette vil følgelig giøre det vanskelig for elevene å forholde seg til teksten. Studiens funn tyder også på at arbeid med utdrag ifølge lærerne gir elevene mindre forståelse for teksten, kontra arbeid med hele verk som lærerne mener gir bedre forståelse.

Noe som kan forklare den store andelen utdrag, er at utdrag og hele verk tjener ulike mål i norskundervisningen. Flere av lærerne i utvalget nevner at utdrag egner seg for å gi elevene breddekunnskaper, og fungerer som illustrasjon og eksemplifisering på for eksempel litterære perioder. Dette samsvarer med Pennes (2012) oppfatning av utdragslesing, som hun mener kan egne seg til å illustrere litterære perioder. Samtidig beskriver flere av lærerne i vår studie arbeid med utdrag som fragmentarisk, 
og at det gir mindre forståelse for teksten. Tendensen ser ut til å være at utdragene først og fremst egner seg til å illustrere litterære perioder, typiske forfattertrekk eller som eksempler på virkemidler og sjangre. Arbeid med hele verk åpner derimot for muligheten til å fordype seg, og gir i følge lærerne i denne studien bedre forståelse for selve teksten. Å legge til rette for at elevene kan gå i dybden, er helt sentralt i arbeidet med fagfornyelsen (NOU 2015:8), og disse mulighetene er forsterket i den nye norskplanen. Oppsummert ser det ut til at formålet med å lese utdrag ligger utenfor teksten - utdraget brukes som middel for å oppnå mål som ligger utenfor den enkelte teksten i seg selv, som for eksempel kunnskap om litteraturhistorie. Det primære formålet med å lese hele verk synes derimot å være forståelse av selve teksten verket utgiør. Flere av lærerne beskriver at arbeid med hele verk giør det mulig å fordype seg i teksten, og at det gir en bedre forståelse for innholdet i verket.

Et annet sentralt funn i denne studien er at visse enkelttekster, deler av Henrik Ibsens forfatterskap og visse tidsperioder er så hyppig brukt i undervisningen på tvers av lærernes klasser, at man kanskje kan snakke om en skjult litterær kanon i skolen. Litteraturkanon i morsmålsfaget er et tema som har vekt stor debatt i Norden de siste årene, blant annet som en konsekvens av at listene over skjønnlitterære forfatterskap ble fjernet med LK06. Samtidig har de litterære tekstene i lese- og lærebøkene stadig blitt kortere og kortere, og verklesingen er svekket (Steinfeld \& Ullström, 2012).Våre funn tyder på at lærebøkene i stor grad er styrende for hvilke tekstutdrag lærerne i utvalget velger å bruke i undervisningen. Dette samsvarer med hva Rogne (2008) trekker frem som en konsekvens av at læreplanen ikke inneholder en eksplisitt kanon, at valget av tekster blir overlatt til læremiddelprodusentene. Lærebøkenes utvalg av tekster kan videre føre til en skjult kanon i norsk skole. Vår studie tyder på at noen litterære tekster er så mye hyppigere brukt enn andre tekster at man trolig kan snakke om en slik skjult kanon. Svaret på Aamotsbakkens (2011) spørsmål om fraværet av lister over forfattere og tekster i Kunnskapsløftet betyr slutten for kanonisert litteratur, ser ut til å være nei - kanonisert litteratur virker fortsatt å være gjeldende i skolen.

Vår analyse viser at de verktitlene som blir nevnt aller flest ganger, er det svært mange av lærerne i utvalget som nevner. For eksempel oppgir over halvparten av lærerne at de leser utdrag fra Sult av Knut Hamsun, og over en tredjedel sier at de leser utdrag fra Amtmannens Døtre (Camilla Collett), Kristin Lavransdatter (Sigrid Undset) eller Albertine (Christian Krogh). I tillegg til at enkelte verktitler nevnes av en stor andel av lærerne i utvalget, er det også én enkeltforfatter som markant skiller seg ut. Henrik Ibsen har skrevet samtlige av de mest leste dramatiske tekstene som nevnes, både når det gjelder utdrag og hele verk. Dette er spesielt viktig fordi flere uttrykte stor bekymring for at Ibsen ikke skulle bli lest da Kunnskapsløftet kom. Både professorer og forfattere mente at den nye læreplanen hadde "utelatt Ibsen", og saken ble slått opp som en nasjonal skandale (Eide, 2006). For eksempel uttrykte både Finn Stenstad (2006) og Kristin Gunleiksrud (2005) bekymring for hvordan 
det ville gå med elevenes kjennskap til Ibsen. Våre funn gir imidlertid tydelige indikasjoner på at Henrik Ibsen og flere av hans verk fortsatt har en sterk og stabil posisjon $i$ litteraturundervisningen, og at man i vårt materiale kan snakke om Ibsen som en kanonisert forfatter.

Studien tyder også på at visse litterære tidsperioder er sterkere representert enn andre. Det er tekster fra 1800-tallet som er hyppigst brukt i undervisningen, der tolv av de 15 mest leste utdragene og 14 av de 15 mest leste hele verkene i de tre sjangerkategoriene, er skrevet innenfor dette århundret. Dette kan være med å bekrefte Aamotsbakkens (2003) hypotese om at 1800-tallets forfatterskap og tekster er kanonisert i skolen. Kanon er nært knyttet til litteraturen fra slutten av 1800-tallet, som hun omtaler som "gullalderen» i norsk litteraturhistorie (Aamotsbakken, 2003, s. 24). Våre funn støtter opp under dette, da analysen viser at det er tekster fra 1880tallet som er hyppigst brukt. En intensjon med den nye norskplanen som kom med LK06 var imidlertid at det skulle bli tatt sterkere utgangspunkt i samtidslitteratur (Eide, 2006).Våre funn tyder på at denne intensjonen i praksis ikke har blitt realisert, da analysen viser at det klart leses flest tekster fra 1800-tallet og at samtidslitteratur i beskjeden grad nevnes av lærerne i utvalget.

Det er vanskelig å angi et spesifikt årstall for når man skal begynne å regne verk som samtidslitteratur, Eirik Vassenden (2007) påpeker at begrepet "samtidslitteratur» har en selvinnlysende betydning og at «alle» trolig skjønner hva man mener med begrepet, men at det likevel innebærer en vag forståelse av hva slags litteratur som kan plasseres inn i en slik periodebetegnelse. Vi har valgt å ta utgangspunkt i Ove Eides (2006) pragmatiske definisjon av samtidslitteratur som omfatter «den litteraturen som er skriven i elevanes levetid» (s. 7). Spørreundersøkelsen ble sendt ut ved oppstarten av skoleåret 2017/2018, og lærernes forrige avgangskull var dermed elever som avsluttet videregående skolegang i 2017. Med forbehold om at disse elevene fullførte skolegangen på normert tid, vil de være født i 1998. Lærerne ble bedt om å besvare undersøkelsen ut ifra hva som vanligvis skjer i en klasse på vg3, og elevgruppen lærerne har svart ut ifra kan dermed også være født før 1998. Videre er lærerne i utvalget alt fra nyutdannede lærere til lærere som har jobbet i skolen i over 30 år. For å avgrense samtidslitteratur, velger vi til tross for dette å ta utgangspunkt i det siste kullet med avgangselever, født i 1998. Med utgangspunkt i Eides (2006) pragmatiske definisjon, som viser til litteratur skrevet i elevenes egen levetid, vil samtidslitteratur i denne studien være litteratur skrevet på 2000-tallet og nyere. Denne avgrensningen samsvarer også med Per Thomas Andersens (2012) beskrivelse av samtidslitteratur, der han påpeker at det er all grunn til å tro at forfatterskap og verk fra 2000-tallet vil være langt mer foreløpige enn eldre litteratur.

Samtidslitteratur er nesten ikke representert blant de mest leste utdragene og hele verkene som lærerne oppgir $i$ vår studie. Kun ett utdrag og ett helt verk, blant de fem mest leste utdragene og hele verkene innen hver av de tre sjangerkategoriene, 
kan kategoriseres som samtidslitteratur etter vår definision (se tabell 1 og 2). Dette gjelder utdrag fra en av romanene fra Karl Ove Knausgårds romansyklus Min kamp (2009-2011) og Bli hvis du kan. Reis hvis du må av Helga Flatland (2010). Selv om det totalt sett nevnes relativt mange ulike verk som kan kategoriseres som samtidslitteratur (44 utdrag og 21 hele verk) utgitt på 2000-tallet, er de fleste av disse tekstene nevnt av én lærer. Til tross for at den nye norskplanen med K06 skulle ta sterkere utgangspunkt i samtidslitteratur, antyder vår undersøkelse at det klart leses flest tekster fra 1800-tallet og at samtidslitteratur i liten grad er representert blant tekstene lærerne oppgir. Trolig kan dette ha en sammenheng med at læreboka i stor grad virker å være styrende for hvilke tekstutdrag lærerne velger å bruke i undervisningen. Formuleringene i læreplanen virker slik ikke å ha så stor innvirkning på lærebøkenes tekstutvalg og hvilke tekster lærerne bruker i undervisningen, og kanonisert litteratur virker i tråd med Aamotsbakkens (2011) hypotese derfor fortsatt å være et tema.

Aamotsbakken (2011) bemerker at det var under den såkalte gullalderen at kvinnelige forfattere begynte å få gjennomslag i offentligheten, men at representasjonen av kvinnelige forfattere likevel er lav i skoleantologier og tilhørende litteraturhistoriske fremstillinger. Dette gjelder både siste del av 1800-tallet og nyere litteratur på 1900-tallet frem til tusenårsskiftet. Våre funn viser at det er en klar overrepresentasjon av mannlige forfattere blant verkene som lærerne oppgir at de vanligvis leser i løpet av vg3. 205 av de totalt 272 verktitlene på utdrag og hele verk som oppgis, $75 \%$, er skrevet av mannlige forfattere. Ser man utdrag og hele verk hver for seg er fordelingen nokså lik, der $76,5 \%$ av utdragene og $72 \%$ av de hele verkene er skrevet av en mannlig forfatter. Over $70 \%$ av alle de ulike verktitlene som lærerne oppgir er altså skrevet av en mannlig forfatter, og bekrefter kvinnelige forfatteres beskjedne plass i litteraturundervisningen (Aamotsbakken, 2011). Studien til Gabrielsen mfl. (til fagfellevurdering) finner også en klar overrepresentasjon av mannlige forfattere blant de skjønnlitterære tekstene som leses i norskfaget. Dersom vi ser på samtidstekstene lærerne i utvalget vårt oppgir, er imidlertid forskjellen mellom kjønnene noe mindre. Blant de samtidslitterære utdragene som nevnes, er 64 \% skrevet av en mannlig forfatter. Når det gjelder samtidstekstene som leses i sin helhet er litt over halvparten av verkene, $57 \%$, skrevet av en kvinnelig forfatter.

Våre funn tyder på at det er den fagspesifikke delen av læreplanen, særlig kompetansemålene, som legger premissene for litteraturarbeidet i undervisningen, og at formålsparagrafen og overordnet del av læreplanen, på bekostning av dette, kommer mer i bakgrunn. Der ser ut til at skolens styringsdokumenter, ikke veldig overraskende, vektes ulikt i undervisningen til lærerne i utvalget. En del av arbeidet med fagfornyelsen er å utarbeide en bedre sammenheng mellom det som nå heter Overordnet del og læreplaner for fag (Kunnskapsdepartementet, 2015). Både formålsparagrafen (Opplæringslova, 1998, $₫ 1-1$ ) og den nye overordnede 
delen av læreplanverket (Utdanningsdirektoratet, 2018), inneholder formuleringer knyttet til viktigheten av å formidle kunnskap om vår egen og andres kultur. Kulturforståelse presiseres også i formålet med norskfaget (Kunnskapsdepartementet, 2013), og er et sentralt moment i Nussbaums $(1997,2010)$ teori om den narrative forestillingsevne. "I en tid der befolkningen er mer sammensatt enn noen gang, og der verden knyttes tettere sammen, blir språkkunnskaper og kulturforståelse stadig viktigere" (Utdanningsdirektoratet, 2018), kan vi lese i den nye overordnede delen av læreplanen. Ut fra lærernes beskrivelser av arbeid med utdrag kontra hele verk vil trolig hele verk egne seg best til å fremme forståelse for ulike kulturer, da hele verk muliggiør fordypning og forståelse for selve teksten. Videre viser våre funn at lærerne mener lesing av utdrag gjør det vanskeligere for elevene å sette seg inn i den fiktive verden til karakterene i teksten, noe som er en forutsetning for å utvikle den narrative forestillingsevnen og kulturforståelse. Likevel viser vår studie at lesing av utdrag er en svært utbredt praksis. Årsaken til dette basert på lærernes svar, er at man rekker å lese flere og at de egner seg til å illustrere litterære epoker, som kan spores tilbake til kompetansemålene i faget.

Til tross for at lærerne har full frihet til å fylle litteraturfaget med det de vil, er det mye som tyder på at de likevel velger mange av de samme tekstene, noe som gir de som frykter mangel på felles referanserammer i norskfaget liten grunn til bekymring. Vi vil snarere argumentere for at det å øke variasjonen i hva som leses og å være kritisk til lærebøkenes styrende rolle bør være en målsetting. Å lese tekster fra ulike tidsperioder og forfattere, knyttet til ulike kulturhistoriske kontekster og elevenes egen samtid, vil være med å fremme innsikt $i$ andre menneskers tanker og livsbetingelser, noe som vektlegges i det nye kjerneelementet «Tekst i kontekst» (Kunnskapsdepartementet, 2018, s. 9). Det er et krevende dilemma med lesing av utdrag kontra hele verk - og vi trenger kanskje begge deler. Vi vil ikke argumentere for at lærere konsekvent bør velge å lese litterære verk i sin helhet, da det trolig alltid vil foreligge et tidspress i skolen som følge av mange skolefag med omfattende innhold. En skal heller ikke undervurdere hvor krevende det kan være å finne ett litterært verk som egner seg godt til en hel klasse med stor variasjon i elevenes lesekompetanse og faglige nivå. Likevel vil vi med utgangspunkt $i$ våre funn åpne for at det å øke andel hele verk bør være en prioritert målsetting i arbeidet med fagfornyelsen i norsk.

\section{Takk}

Vi vil takke redaktøren og de anonyme fagfellene for konstruktive tilbakemeldinger og gode innspill. Vi vil også takke stipendiatene Ida Lodding Gabrielsen og Camilla Gudmundsdatter Magnusson ved Institutt for lærerutdanning og skoleforskning, UIO, for gjennomlesing og kloke råd. 


\section{Forfatteromtale}

Marte Blikstad-Balas er professor i norskdidaktikk ved Universitetet i Oslo, Institutt for lærerutdanning og skoleforskning. Hun forsker primært på lesing og skriving i skolen og har en rekke tidligere publikasjoner knyttet til disse temaene. Hun underviser i norskdidaktikk og i forskningsmetode ved UiO.

Sigrid Skaug har en master i norskdidaktikk fra Universitetet i Oslo. Hennes masteravhandling handler om hvilke tekster norsklærere i vg3 velger å bruke i undervisningen sin, og deres refleksjoner rundt disse valgene. Det er fra denne masteravhandlingen datamaterialet i artikkelen stammer fra.

\section{Referanser}

Aamotsbakken, B. (2003). Skolens kanon - vår viktigste lesedannelse?: En studie $i$ kanonisering $i$ norskfaglige antologier for videregående skole, allmennfaglig studieretning. Hentet fra http:/www-bib.hive.no/tekster/ hveskrift/rapport/2003-09/rapp9-2003.pdf

Aamotsbakken, B. (2011). Skolereformer og kanon. I D. Skjelbred \& B. Aamotsbakken (Red.), Norsk larebokhistorie III - en kultur- og danningshistorie (s. 103-119). Oslo: Novus.

Aamotsbakken, B. (2018) Kanon - hvorfor og hvordan? I K. Kverndokken (Red.), 101 litteraturdidaktiske grep (s. 74-88). Bergen: Fagbokforlaget.

Andersen, P. T. (2012). Norsk litteraturhistorie (2. utg.). Oslo: Universitetsforlaget.

Aase, L. (2005). Skolefagenes ulike formål - danning og nytte. I K. Børhaug, A. Fenner \& L. Aase (Red.), Fagenes begrunnelser: skolens fag og arbeidsmåter $i$ danningsperspektiv (s. 15-28). Bergen: Fagbokforlaget.

Berge, K. L. (2012). Retorisk dannelse som grunnlag for demokratisk medborgerskap i skolen: om de grunnleggende ferdighetene skriving og muntlighet i Kunnskapsløftet. I K. L. Berge \& J. H. Stray (Red.), Demokratisk medborgerskap i skolen (s. 79-101). Bergen: Fagbokforlaget.

Bruner, J. S. (1996). The culture of education. Cambridge, Massachusetts: Harvard University Press.

Cohen, L., Manion, L., \& Morrison, K. (2011). Research methods in education (7. utg.). London: Routhledge.

Cresswell, J. W. (2014). Research design: qualitative, quantitative, and mixed methods approaches (4. utg.). Los Angeles, Calif: SAGE.

Eide, O. (2006). Frå kanon til literacy? Det nye norskfaget i nærlys og perspektiv. Norsklceraren, 30(2), 6-13.

Eyde, B., \& Skovholt, K. (2017). Debatten i norskfaget - en oppsummering. Norsklceraren, 41(1), 10-14.

Fodstad, L. A. (2017). Hva jeg snakker om når jeg snakker om norskfaget. Noen strøtanker om litteratur, literacy og læring. Norsklceraren,41(1) 7-24.

Fowler, F. J. (2009). Survey research methods (4. utg.). Los Angeles: SAGE.

Gabrielsen, I., Blikstad-Balas, M., \& Tengberg, M. (til fagfellevurdering). The role of literature in the classroom: How and for what purposes do teachers in lower secondary school use literary texts? Innsendt til L1 Educational Studies in Language and Literature.

Gilje, N., \& Grimen, H. (1993). Samfunnsvitenskapenes forutsetninger: innføring $i$ samfunnsvitenskapenes vitenskapsfilosofi (3. utg.). Oslo: Universitetsforlaget.

Gunleiksrud, K. (2005, 28.april). Er dette et kunnskapsløft? Dagbladet. Hentet fra https://www.dagbladet.no/ kultur/er-dette-et-kunnskapsloft/66090061

Hamre, P. (2014). Norskfaget og skjønnlitteraturen. Ein studie av norskfaglege normtekstar 1739-2013 (Doktorgradsavhandling, Universitetet i Bergen). Hentet fra http://bora.uib.no/bitstream/handle/1956/8667/ dr-thesis-2014-Pål-Hamre.pdf?sequence=2\&isAllowed=y

Hsieh, H. F., \& Shannon, S. E. (2005). Three Approaches to Qualitative Content Analysis. Qualitative Health Research, 15(9), 1277-1288. Hentet fra http://journals.sagepub.com/doi/pdf/10.1177/1049732305276687

Hærgard, M. L., \& Engh, K. Ø. (2013). Skjønnlitteraturens muligheter $i$ samfunnsfag (Mastergradsavhandling, Universitetet i Oslo). Hentet fra https:/www.duo.uio.no/bitstream/handle/10852/37795/Engh-HaergardMaster.pdf?sequence $=1$ \&isAllowed $=y$

Kjelen, H. (2018). Å vere litteraturlærar. I K. Kverndokken (Red.), 101 litteraturdidaktiske grep (s. 17-38). Bergen: Fagbokforlaget 


\section{Hele tekster versus utdrag - hvilke tekster velger norsklcererne?}

Klette, K., Blikstad-Balas, M., \& Roe, A. (2017). Linking Instruction and Student Achievement - Research design for a new generation of classroom studies. Acta Didactica Norge, 11(3), 1-19. Hentet fra https:// www.journals.uio.no/index.php/adno/article/view/4729/4905

Kunnskapsdepartementet. (2013). Lcereplan i norsk (NOR1-05). Hentet fra https://www.udir.no/k106/NOR1-05

Kunnskapsdepartementet. (2015). Fag - Fordypning - Forståelse: En fornyelse av Kunnskapsløftet. (Meld. St. 28 2015-2016). Hentet fra https://www.regjeringen.no/no/dokumenter/meld.-st.-28-20152016/id2483955/

Kunnskapsdepartementet. (2018). Kjerneelementer $i$ fag. Hentet fra https://www.regjeringen.no/contentassets/ 3d659278ae55449f9d8373fff5de4f65/kjerne elementer-i-fag-for-utforming-av-lareplaner-for-fag-i-lk20-og$1 \mathrm{k} 20$ s-fastsatt-av-kd.pdf

NOU 2015:8. (2015). Fremtidens skole - Fornyelse av fag og kompetanser. Hentet fra https://www.regjeringen.no/ no/dokumenter/nou-2015-8/id2417001/sec1

Nussbaum, M. C. (1997). Cultivating humanity: a classical defense of reform in liberal education. Cambridge, Mass: Harvard University Press.

Nussbaum, M. C. (2010). Not for profit: why democracy needs the humanities. Princeton, New Jersey: Princeton University Press.

Opplæringslova. (1998). Lov om grunnskolen og den vidaregåande opplæringa 17.juli nr. 61. Hentet fra https:// lovdata.no/dokument/NL/lov/1998-07-17-61

Penne, S. (2006). Profesjonsfaget norsk $i$ en endringstid: Norsk på ungdomstrinnet. Å konstruere mening, selvforståelse og identitet gjennom språk og tekster. Fagets rolle $i$ et identitetsperspektiv, $i$ et likhet-og et ulikhetsperspektiv (Doktorgradsavhandling, Universitet i Oslo). Hentet fra http://www.uv.uio.no/ils/forskning/publikasjoner/ rapporter-og-avhandlingen/Penne[1].pdf

Penne, S. (2010). Litteratur og film i klasserommet: didaktikk for ungdomstrinn og videregående skole. Oslo: Universitetsforlaget.

Penne, S. (2012). Når delen erstatter helheten: litterære utdrag og norskfagets lærebøker I R. Solheim, D. K. Sjøhelle, \& S. Matre (Red.), Teorier om tekst $i$ møte med skolens lese- og skrivepraksiser (s. 163-174). Oslo: Universitetsforlaget.

Penne, S. (2013). Skjønnlitteraturen i skolen i et literacy-perspektiv. I D. Skjelbred \& A. Veum (Red.), Literacy $i$ leringskontekster (s. 42-54). Oslo: Cappelen Damm.

Rogne, M. (2008). Mot eit moderne norskfag. Tekstomgrepet i norskplanane. Acta Didactica Norge, 2(1), 1-24. Hentet fra https:/www.journals.uio.no/index.php/adno/article/viewFile/1021/900

Rødnes, K. A. (2014). Skjønnlitteratur i klasserommet: Skandinavisk forskning og didaktiske implikasjoner. Acta Didactica Norge, 8(1), 1-17. Hentet fra https://www.journals.uio.no/index.php/adno/article/view/1097/976

Schüllerqvist, I. M. (2008). Läsa texten eller "verkligheten": Tolkningsgemenskaper på en litteraturdidaktisk bro (Doktorgradsavhandling, Stockholms universitet). Hentet fra http://su.diva-portal.org/smash/record. jsf?pid= diva2 $\% 3 \mathrm{~A} 198476 \&$ dswid $=5232$

Skaftun, A., \& Michelsen, P. A. (2017). Litteraturdidaktikk. Oslo: Cappelen Damm akademisk.

Skjelbred, D., Askeland, N., Maagerø, E., \& Aamotsbakken, B. (2017). Norsk larebokhistorie: allmueskolen, folkeskolen, grunnskolen: 1739-2013. Oslo: Universitetsforlaget.

Smidt, J. (2018). Norskfaget mellom fortid og fremtid. Bergen: Fagbokforlaget.

Steinfeld, T., \& Ullström, S. O. (2012). Litteraturdidaktikk. I P. T. Andersen, G. Mose \& T. Norheim (Red.), Littercer analyse. En innføring (s. 226-241). Oslo: Pax Forlag.

Stenstad, F. (2006, 02.desember). Henrik Ibsen, hvem er det? Aftenposten. Hentet fra https://www.aftenposten. no/meninger/kronikk/i/5GwxK/Henrik-Ibsen_-hvem-er-det

Utdanningsdirektoratet. (2018). Overordnet del av lereplanverket. Hentet fra https:/www.udir.no/laring-ogtrivsel/lareplanverket/overordnet-del/

Vassenden, E. (2007). Hva er «samtidslitteratur», og hvorfor leser vi den? - Noen begrepshistoriske og fagkritiske bemerkninger. Edda, 94(4), 357-371. Hentet fra https://www.idunn.no/edda/2007/04/hva_er_samtidslitteratur_ og_hvorfor_leser_vi_den_-_noen_begrepshistoriske_o 


\section{Vedlegg 1: Spørreskjema}

\section{Lesing av skjønnlitteratur}

Denne undersøkelsen fokuserer på undervisningen som foregår i norsktimene på vg3 på studieforberedende utdanningsprogram og påbygging til generell studiekompetanse. Det er lesing av skjønnlitterære utdrag og hele verk som tematiseres. Dersom du har andre klasser bes du om å besvare undersøkelsen ut fra hva som vanligvis skjer i en vg3-klasse. Undersøkelsen er anonym.

Kjønn

Mann

Kvinne

Alder
20-29 år
30-39 år
40-49 år
50-60 år
Over 60 år

Antall år i skolen
0-2 âr
3-5 ár
6-10 år
11-20 år
21-30 år
Over 30 år

Underviser du på studiespesialiserende eller påbygg?

Kryss av for det alternativet du velger á besvare denne undersøkelsen ut i fra dersom du underviser på begge retninger

Studiespesialiserende

Påbygg

Ansatt i fylke?

国 Sideskift

Hvilke skjønnlitterære utdrag leser klassen din vanligvis i løpet av vg3?

Skriv en liste over utdrag du kammer pá.

Hvilke skjønnlitterære hele verk leser klassen din vanligvis i løpet av vg3?

Skriv en liste over verk du kommer pá. 


\title{
Bruker du mest utdrag eller hele verk?
}

\author{
Utdrag \\ Hele verk \\ 邑 Sideskift
}

\section{Bruk av utdrag}

\begin{tabular}{|lccccc|}
\hline & Aldri & Sjelden & Noen ganger & Ofte & Altid \\
\hline Jeg har selv lest originalteksten utdraget kommer fra & 0 & 0 & 0 & 0 & 0
\end{tabular}

\section{Hvor kommer utdragene fra?}

\begin{tabular}{|c|c|c|c|c|c|}
\hline & Aldri & Sjelden & Noen ganger & Ofte & Alltid \\
\hline Læreboka eller lærebokas tekstsamling & $\bigcirc$ & 0 & $\bigcirc$ & $\bigcirc$ & $\bigcirc$ \\
\hline Andre lærebøker enn den klassen bruker & $\bigcirc$ & $\mathrm{O}$ & $\mathrm{O}$ & 0 & $\bigcirc$ \\
\hline Lager selv fra originaltekster (for eksempel en roman) & $\bigcirc$ & $\bigcirc$ & 0 & 0 & $\bigcirc$ \\
\hline
\end{tabular}

Hvilke skjønnlitterære sjangre leser dere utdrag fra?

\begin{tabular}{|c|c|c|c|c|c|}
\hline & Aldri & Sjelden & Noen ganger & Ofte & Alltid \\
\hline Lyriske tekster & 0 & 0 & 0 & 0 & 0 \\
\hline Noveller & 0 & 0 & 0 & 0 & 0 \\
\hline Romaner & O & 0 & 0 & 0 & 0 \\
\hline Dramatiske verk & 0 & 0 & 0 & 0 & 0 \\
\hline Fra andre skjønnlitterære sjangere enn nevnt ovenfor & 0 & 0 & 0 & 0 & 0 \\
\hline
\end{tabular}

邑 Sideskitt

Hva er formålet med å lese utdrag fra litterære verk?

\begin{tabular}{|c|c|c|c|c|c|}
\hline & Aldri & Sjelden & Noen ganger & Ofte & Alltid \\
\hline A kjenne til den litterære perioden & 0 & 0 & 0 & 0 & 0 \\
\hline A kjenne til forfatteren & 0 & 0 & 0 & 0 & 0 \\
\hline A analysere/tolke/reflektere & 0 & 0 & 0 & 0 & 0 \\
\hline Á bidra til dannelse og identitetsutvikling & 0 & 0 & 0 & 0 & 0 \\
\hline A skape leselyst & 0 & 0 & 0 & 0 & 0 \\
\hline
\end{tabular}




\section{S. Skaug og M. Blikstad-Balas}

隹 Sideskift

Hva er formálet med å lese hele litterære verk?

\begin{tabular}{|c|c|c|c|c|c|}
\hline & Aldri & Sjelden & Noen ganger & Ofte & Alltid \\
\hline A kjenne til den litterære perioden & 0 & 0 & O & 0 & 0 \\
\hline A kjenne til forfatteren & O & 0 & O & $\bigcirc$ & 0 \\
\hline A analysere/tolke/reflektere & $\bigcirc$ & $\bigcirc$ & O & 0 & 0 \\
\hline A bidra til dannelse og identitetsutvikling & 0 & $\bigcirc$ & $\bigcirc$ & $\bigcirc$ & O \\
\hline A skape leselyst & O & 0 & 0 & 0 & $\mathrm{O}$ \\
\hline
\end{tabular}

ゆ Sideskift

Dersom dere leser hele verk, hvor foregår lesingen?

\begin{tabular}{|c|c|c|c|c|c|}
\hline & Aldri & Sjelden & Noen ganger & Ofte & Alltid \\
\hline Individuell stillelesing på skolen & 0 & O & 0 & $\mathrm{O}$ & $\mathrm{O}$ \\
\hline Høytlesing på skolen & 0 & 0 & 0 & 0 & O \\
\hline Lesing i mindre grupper på skolen & 0 & 0 & 0 & $\bigcirc$ & $\bigcirc$ \\
\hline Lesing hjemme & $\mathrm{O}$ & $\bigcirc$ & $\mathrm{O}$ & $\mathrm{O}$ & $\bigcirc$ \\
\hline
\end{tabular}

Hvordan velger du ut hvilke tekster som skal leses?

\begin{tabular}{|l|l|}
\hline Samarbeid med de andre norsklærerne på trinnet \\
\hline Samarbeid med bibliotekaren på skolen & Aldri Sjelden Noen ganger \\
\hline Jeg velger tekster på bakgrunn av norsklærerutdanningen min \\
\hline Jeg velger tekster pá bakgrunn av egen fritidslesing \\
\hline Jeg bruker lærebokas utvalg av tekster \\
\hline Jeg bruker andre lærebøkers utvalg av tekster
\end{tabular}

ほ Sideskift

Hvor enig eller uenig er du i følgende pástander?

Helt uenig Uenig Verken eller Enig Helt enig

Jeg liker å bruke flere utdrag fra de ulike litterære epokene

Jeg liker á bruke hele verk for á fremstille en litterær epoke

Jeg skulle ønske det var mer tid til å lese hele verk

$\begin{array}{lllll}0 & 0 & 0 & 0\end{array}$


厓 Sideskift

Hva synes du er den største forskjellen med å arbeide med utdrag kontra hele verk?

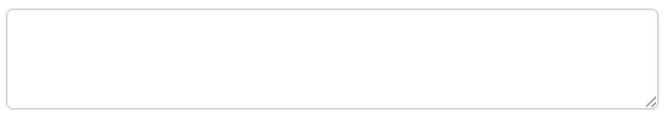

邑 Sideskift

Hvor enig eller uenig er du i følgende pástander?

Helt uenig Uenig Verken eller Enig Helt enig

Jeg foretrekker heller á arbeide med utdrag enn med hele verk

Jeg foretrekker heller å arbeide med hele verk enn utdrag

Jeg tror at elevene mine heller foretrekker â lese utdrag enn hele verk

Jeg tror at elevene mine heller foretrekker â lese hele verk enn utdrag

$\equiv$ Sideskift

Hvor enig eller uenig er du i følgende pástander?

Helt uenig Uenig Verken eller Enig Helt enig

Jeg synes det er utfordrende å lese utdrag i klassen

Jeg synes lesing av utdrag gjør det vanskeligere for elevene å få en helhetsforståelse av det de har lest

Jeg tror elevene mine oppnår en like grundig og god forståelse av å lese utdrag som å lese hele verk

Jeg tror elevene mine oppnår en grundigere og bedre forståelse av å lese hele verk enn å lese utdrag

झ Sideskift

Hvor enig eller uenig er du i følgende påstander?

Helt uenig Uenig Verken eller Enig Helt enig

Det er vanskelig å velge ut hvilke litterære verk som skal brukes i undervisningen

Jeg skulle ønske det var fastsatt i læreplanen hvilke litterære verk som skal brukes i undervisningen

Vi har tilstrekkelig med tid til å fordype oss i de ulike litterære tekstene vi leser

Vi har for liten tid til å lese hele verk i undervisningen

0

$0 \quad 0$

Jeg skulle ønske vi hadde tid til â lese hele verket som utdraget kommer fra

Dersom vi hadde hatt bedre tid ville jeg lest mer hele verk

Det er vanskelig å motivere elevene mine til å lese hele verk fordi de er lange og tidkrevende

Jeg prøver á unngå hele verk fordi de ofte er lange og tidkrevende 


\section{S. Skaug og M. Blikstad-Balas}

E Sideskif

Hvor enig eller uenig er du i følgende pástander?

Helt uenig Uenig Verken eller Enig Helt enig

Lesing av utdrag gjør at det er vanskeligere for elevene å sette seg inn i den fiktive verden til karakterene i teksten (for eksempel føle sinne eller

medfølelse overfor noen av karakterene)

Elevene mine klarer å leve seg like mye inn i et utdrag som i et helt litterært verk

Sideskift

Dybdelæring står sentralt i Ludvigsenutvalgets utredning om fremtidens skole

"Dybdelæring dreier seg om elevenes gradvise utvikling av forståelse av begreper, begrepssystemer, metoder og sammenhenger innenfor et fagområde. Det handler ogsá om å forstá temaer og problemstillinger som gár pá tvers av fag- eller kunnskapsomráder. Dybdelæring innebærer at elevene bruker sin evne til á analysere, løse problemer og reflektere over egen læring til á konstruere en varig forstảelse" (NOU 2015: 8, s. 14).

\section{Hvor enig eller uenig er du i følgende påstander?}

\begin{tabular}{|l|l|}
\hline Det bør leses færre utdrag for å få til dybdelæring & Helt uenig Uenig Verken eller \\
\hline Dybdelæring er vanskelig å få til når vi leser utdrag & Helt enig \\
\hline Elevene klarer å tilegne seg dybdeforståelse når vi leser utdrag \\
\hline Det bør leses flere hele verk for å få til dybdelæring \\
\hline Dybdelæring er lettere å få til når vi leser hele verk \\
\hline Dagens læreplan i norsk legger godt til rette for elevenes dybdelæring \\
\hline E Sideskift
\end{tabular}

Ludvigsenutvalget skriver i sin rapport:

"A utvikle lesekompetanse handler om á kunne forstá, bruke, reflektere over, vurdere kritisk og engasjere seg i innholdet i tekster" (NOU 2015: 8, s. 28).

Hvor ofte synes du lesing av utdrag bidrar til dette?

Aldri Sjelden Nøytral Ofte Alltid

Hvor ofte synes du lesing av hele verk bidrar til dette?

邑 Sideskift

Etter din mening, hva er det viktigste for å fả til dybdelæring ved lesing av skjønnlitteratur?

Tusen takk for at du tok deg tid til á svare pá undersøkelsen! 
Hele tekster versus utdrag - hvilke tekster velger norsklcererne?

Vedlegg 2: Tabelloversikt over respondentenes bakgrunnsvariabler

\begin{tabular}{|c|c|c|}
\hline & Antall & I prosent \\
\hline \multicolumn{3}{|l|}{ Kjønn } \\
\hline Mann & 30 & 19,7 \\
\hline Kvinne & 122 & 80,3 \\
\hline \multicolumn{3}{|l|}{ Alder } \\
\hline $20-29$ & 9 & 5,9 \\
\hline $30-39$ & 42 & 27,5 \\
\hline $40-49$ & 66 & 43,1 \\
\hline $50-60$ & 16 & 10,5 \\
\hline Over 60 & 20 & 13,1 \\
\hline \multicolumn{3}{|l|}{ Antall år i skolen } \\
\hline $0-2$ & 2 & 1,3 \\
\hline $3-5$ & 14 & 9,3 \\
\hline $6-10$ & 32 & 21,2 \\
\hline $11-20$ & 71 & 47 \\
\hline $21-30$ & 15 & 9,9 \\
\hline Over 30 & 17 & 11,3 \\
\hline \multicolumn{3}{|l|}{ Studieretning } \\
\hline Studiespesialiserende & 126 & 82,4 \\
\hline Påbygg & 27 & 17,6 \\
\hline \multicolumn{3}{|l|}{ Ansatt i fylke } \\
\hline Østfold & 9 & 5,9 \\
\hline Akershus & 11 & 7,2 \\
\hline Oslo & 5 & 3,3 \\
\hline Hedmark & 17 & 11,1 \\
\hline Oppland & 7 & 4,6 \\
\hline Buskerud & 11 & 7,2 \\
\hline Vestfold & 7 & 4,6 \\
\hline Telemark & 1 & 0,7 \\
\hline Aust-Agder & 6 & 3,9 \\
\hline Vest-Agder & 11 & 7,2 \\
\hline Rogaland & 7 & 4,6 \\
\hline Hordaland & 8 & 5,2 \\
\hline Sogn og Fjordane & 17 & 11,1 \\
\hline Møre og Romsdal & 9 & 5,9 \\
\hline Sør-Trøndelag & 7 & 4,6 \\
\hline Nord-Trøndelag & 9 & 5,9 \\
\hline Nordland & 5 & 3,3 \\
\hline Troms & 3 & 2 \\
\hline Finnmark & 2 & 1,3 \\
\hline "Trønderlag" & 1 & 0,7 \\
\hline
\end{tabular}




\section{S. Skaug og M. Blikstad-Balas}

\section{Vedlegg 3: Tabelloversikt over utdrag}

\begin{tabular}{|c|c|c|}
\hline Verk & Utgitt & Frekvens \\
\hline \multicolumn{3}{|l|}{ Romaner } \\
\hline Sult (Knut Hamsun) roman & 1890 & 96 \\
\hline Amtmandens Døtre (Camilla Collet) roman & 1855 & 64 \\
\hline Kristin Lavransdatter - én av dem (Sigrid Undset) romansyklus & $1920-1922$ & 61 \\
\hline Albertine (Christian Krogh) roman & 1886 & 59 \\
\hline Min Kamp - én av dem (Karl Ove Knausgård) romansyklus & $2009-2011$ & 33 \\
\hline Forrådt (Amalie Skram) roman & 1892 & 26 \\
\hline Gymnaslarer Pedersen (Dag Solstad) roman & 1982 & 19 \\
\hline Markens Grøde (Knut Hamsun) roman & 1917 & 18 \\
\hline Hellemyrsfolket - én av dem (Amalie Skram) romansyklus & $1887-1898$ & 17 \\
\hline Medmenneske (Olav Duun) roman & 1929 & 17 \\
\hline$L$ (Erlend Loe) roman & 1999 & 16 \\
\hline Alle utlendinger har lukka gardiner (Maria Navarro Skaranger) roman & 2015 & 15 \\
\hline En flyktning krysser sitt spor (Aksel Sandemose) roman & 1933 & 14 \\
\hline fuvikfolket - én av dem (Olav Duun) romansyklus & 1923 & 14 \\
\hline Naiv. Super (Erlend Loe) roman & 1996 & 14 \\
\hline Ulysses (James Joyse) roman & 1922 & 13 \\
\hline fonas (Jens Bjørneboe) roman & 1955 & 13 \\
\hline Sjur Gabriel (Amalie Skram) roman & 1887 & 12 \\
\hline Innsirkling - én av dem (Carl Frode Tiller) roman & $2007,2010,2014$ & 12 \\
\hline Gift (Alexander Kielland) roman & 1883 & 12 \\
\hline Pan (Knut Hamsun) roman & 1894 & 11 \\
\hline Niels Klims underjordiske reise (Ludvig Holberg) roman & 1741 & 9 \\
\hline Kjarlighet (Hanne Ørstavik) roman & 1997 & 9 \\
\hline Frankenstein (Mary Shelly) roman & 1818 & 7 \\
\hline Egalias døtre (Gerd Brantenberg) roman & 2013 & 6 \\
\hline Fuglane (Tarjei Vesaas) roman & 1957 & 6 \\
\hline Fred (Arne Garborg) roman & 1892 & 6 \\
\hline Victoria (Knut Hamsun) roman & 1898 & 6 \\
\hline Beatles (Lars Saabye Christensen) roman & 1984 & 6 \\
\hline Professor Andersens natt (Dag Solstad) roman & 1996 & 6 \\
\hline Snø vil falle over snø som har falt (Levi Henriksen) roman & 2004 & 5 \\
\hline Uten en tråd (Jens Bjørneboe) roman & 1966 & 5 \\
\hline Prosessen (Franz Kafka) roman & 1925 & 5 \\
\hline Madame Bovary (Gustave Flaubert) roman & 1857 & 4 \\
\hline
\end{tabular}




\section{Hele tekster versus utdrag - hvilke tekster velger norsklcererne?}

\begin{tabular}{|c|c|c|}
\hline Verk & Utgitt & Frekvens \\
\hline Gullivers reiser (Jonathan Swift) roman & 1726 & 4 \\
\hline Don Quijote (Miguel de Cervantes) roman & 1605 & 4 \\
\hline Doppler (Erlend Loe) roman & 2004 & 4 \\
\hline Isslottet (Tarjei Vesaas) roman & 1963 & 4 \\
\hline Bikubesong (Frode Grytten) kollektivroman & 1999 & 4 \\
\hline Bergens kapitelsbok (Absalon Pederssøn Beyer) dagbok & $1552-1572$ & 4 \\
\hline Ut å stjcele hester (Per Petterson) roman & 2003 & 4 \\
\hline 1964 (Ragnar Hovland) roman & 2007 & 3 \\
\hline Oliver Twist (Chales Dickens) roman & 1838 & 3 \\
\hline Naustet (Jon Fosse) roman & 1989 & 3 \\
\hline Hvem bestemmer over Bjørg og Unni (Liv Kølzow) roman & 2014 & 3 \\
\hline Til fyret (Viginia Woolf) roman & 1927 & 3 \\
\hline Amatøren (Lars Saabye Christensen) roman & 1977 & 3 \\
\hline Nattens brød (Johan Falkberget) roman & 1940 & 3 \\
\hline Syndere $i$ sommersol (Sigurd Hoel) roman & 1927 & 3 \\
\hline Av måneskinn gror det ingenting (Torborg Nedreaas) roman & 1947 & 2 \\
\hline Hundre års ensomhet (Gabriel García Márquez) roman & 1967 & 2 \\
\hline Lillelord (Johan Borgen) roman & 1955 & 2 \\
\hline Garman $\mathcal{E}$ Worse (Alexander Kielland) roman & 1880 & 2 \\
\hline Før jeg brenner ned (Gaute Heivoll) roman & 2010 & 2 \\
\hline En sjømann går $i$ land (Aksel Sandemose) roman & 1931 & 2 \\
\hline Kruttårnet (Jens Bjørneboe) roman & 1969 & 2 \\
\hline Morfar, Hitler og jeg (Ida Jackson) roman & 2014 & 2 \\
\hline Stigninger og fald (Josefine Klougart) roman & 2010 & 2 \\
\hline Sangen om den røde rubin (Agnar Mykle) roman & 1956 & 2 \\
\hline Genanse og verdighet (Dag Solstad) roman & 1994 & 2 \\
\hline Kompani Orheim (Tore Renberg) roman & 2005 & 1 \\
\hline På sporet av den tapte tid (Marcel Proust) roman & 1913 & 1 \\
\hline Ulvehiet (Oskar Braaten) roman & 1919 & 1 \\
\hline Det store spelet (Tarjei Vesaas) roman & 1934 & 1 \\
\hline Veien til verdens ende (Sigurd Hoel) roman & 1933 & 1 \\
\hline Drageløperen (Khaled Hosseini) roman & 2008 & 1 \\
\hline Heinrich von Ofterdingen (Novalis) roman & 1802 & 1 \\
\hline Bokhandleren i Kabul (Åsne Seierstad) roman & 2002 & 1 \\
\hline Hunger games (Suzanne Collins) roman & 2008 & 1 \\
\hline Sterk sult, plutselig kvalme (Trude Marstein) roman & 1998 & 1 \\
\hline
\end{tabular}




\section{S. Skaug og M. Blikstad-Balas}

\begin{tabular}{|c|c|c|}
\hline Verk & Utgitt & Frekvens \\
\hline Kafka på stranden (Haruki Murakami) roman & 2002 & 1 \\
\hline Trekkoppfuglen (Haruki Murakami) roman & 1994 & 1 \\
\hline Fru Marta Oulie (Sigrid Undset) roman & 1907 & 1 \\
\hline Ung må verden ennu vere (Nordahl Grieg) roman & 1938 & 1 \\
\hline 25. septemberplassen (Dag Solstad) roman & 1974 & 1 \\
\hline Arild Asnes 1970 (Dag Solstad) roman & 1971 & 1 \\
\hline Det er jeg som er Torvald (Mattis Herman Nyquist) roman & 2015 & 1 \\
\hline Huckleberry Finn (Mark Twain) roman & 1884 & 1 \\
\hline Magnet (Lars Saabye Christensen) roman & 2015 & 1 \\
\hline Skråninga (Carl Frode Tiller) roman & 2001 & 1 \\
\hline Den unge Werthers lidelser (Johann Wolfgang von Goethe) roman & 1774 & 1 \\
\hline Begynnelser (Carl Frode Tiller) roman & 2017 & 1 \\
\hline Lucie (Amalie Skram) roman & 1888 & 1 \\
\hline Ladies (Mara Lee) roman & 2008 & 1 \\
\hline Odinsbarn (Siri Pettersen) roman & 2013 & 1 \\
\hline Livsslaven (Jonas Lie) roman & 1883 & 1 \\
\hline Hvite niggere (Ingvar Ambjørnsen) roman & 1986 & 1 \\
\hline Pornopung (Mads Larsen) roman & 2003 & 1 \\
\hline Constance ring (Amalie Skram) roman & 1885 & 1 \\
\hline Meg eier ingen (Åsa Linderborg) selvbiografisk roman & 2007 & 1 \\
\hline Pakkis (Khalid Hussain) roman & 1986 & 1 \\
\hline 23-salen (Ingvar Ambjørnsen) roman & 1981 & 1 \\
\hline Forføreren (Jan Kjærstad) roman & 1993 & 1 \\
\hline Hvis en reisende en vinternatt (Italo Calvino) roman & 2000 & 1 \\
\hline Mannen som elsket Yngve (Tore Renberg) roman & 2003 & 1 \\
\hline Flommen (Jonny Halberg) roman & 2000 & 1 \\
\hline Menn som hater kvinner (Stig Larsson) roman & 2005 & 1 \\
\hline Snømannen (Jo Nesbø) roman & 2007 & 1 \\
\hline Alt inkludert (Marit Eikemo) roman & 2015 & 1 \\
\hline Homo Falsus, eller det perfekte mord (Jan Kjærstad) roman & 1984 & 1 \\
\hline Kvinnen og den svarte fuglen (Nini Roll Anker) roman & 1945 & 1 \\
\hline Kongen (Kristofer Uppdal) roman & 1920 & 1 \\
\hline Opptegnelser fra et kjellerdyp (Fjodor Dostojevskij) roman & 1864 & 1 \\
\hline Fatso (Lars Ramslie) roman & 2003 & 1 \\
\hline Mors og fars historie (Edvard Hoem) roman & 2005 & 1 \\
\hline I blinda (Olav Duun) roman & 1919 & 1 \\
\hline Fra Kristiania-bohemen (Hans Jæger) roman & 1885 & 1 \\
\hline
\end{tabular}




\section{Hele tekster versus utdrag - hvilke tekster velger norsklererne?}

\begin{tabular}{|c|c|c|}
\hline Verk & Utgitt & Frekvens \\
\hline Haiene (Jens Bjørneboe) roman & 1974 & 1 \\
\hline Bestialitetens historie (Jens Bjørneboe) roman & 2002 & 1 \\
\hline American psycho (Bret Easton Ellis) roman & 1991 & 1 \\
\hline Skyskraperengler (Tove Nilsen) roman & 1982 & 1 \\
\hline Robinson Crusoe (Daniel Defoe) roman & 1719 & 1 \\
\hline Fenny (Sigrid Undset) roman & 1911 & 1 \\
\hline Mannfolk (Arne Garborg) roman & 1886 & 1 \\
\hline Mrs. Dalloway (Virginia Woolf) roman & 1925 & 1 \\
\hline The Coca Hola Company (Matias Faldbakken) roman & 2011 & 1 \\
\hline Trette mand (Arne Garborg) roman & 1891 & 1 \\
\hline \multicolumn{3}{|l|}{ Noveller } \\
\hline Karens jul (Amalie Skram) novelle & 1885 & 16 \\
\hline Karen (Alexander Kielland) novelle & 1882 & 16 \\
\hline Ballstemning (Alexander Kielland) novelle & 1879 & 8 \\
\hline Kruttrøyk (Torborg Nedreaas) novelle & 1945 & 5 \\
\hline Det røde gardin (Amallie Skram) novelle & 1899 & 4 \\
\hline Faderen (Bjørnstjerne Bjørnson) novelle & 1860 & 4 \\
\hline En god samvittighet (Alexander Kielland) novelle & 1880 & 4 \\
\hline En middag (Alexander Kielland) novelle & 1879 & 4 \\
\hline Fall (Tarjei Vesaas) novelle & 1952 & 4 \\
\hline Dekameronen (Giovanni Boccacio) novellesamling & $1348-1353$ & 3 \\
\hline Drift (Rolf Stenersen) novelle & 1931 & 3 \\
\hline En middag (Alexander Kielland) novelle & 1879 & 3 \\
\hline Inkognito (Kristin Lind) novelle & 2014 & 2 \\
\hline Mens hjula står (Oskar Braaten) novellesamling & 1916 & 2 \\
\hline Luren (Maurits Hansen) novelle & 1819 & 2 \\
\hline Kremmerhuset (Oskar Braaten) novelle & 1930 & 2 \\
\hline Ringen (Knut Hamsun) novelle & 1897 & 2 \\
\hline Kunsten å myrde (Cora Sandel) novelle & 1935 & 2 \\
\hline Skolegutt (Laila Stien) novelle & 1979 & 1 \\
\hline Lillebror (Aksel Sandemose) novelle & 1965 & 1 \\
\hline Naken (Tarjei Vesaas) novelle & 1998 & 1 \\
\hline Idealtid (Lars Saabye Christensen) novelle & 1993 & 1 \\
\hline En ganske alminnelig flue av middels størrelse (Knut Hamsun) novelle & 1895 & 1 \\
\hline Mikke Mus (Erna Osland) novelle & 2004 & 1 \\
\hline Pälsen (Hjalmar Söderberg) novelle & 1898 & 1 \\
\hline Carl (Kjell Askildsen) novelle & 1981 & 1 \\
\hline
\end{tabular}




\section{S. Skaug og M. Blikstad-Balas}

\begin{tabular}{|c|c|c|}
\hline \multicolumn{3}{|l|}{ (Fortsatte) } \\
\hline Verk & Utgitt & Frekvens \\
\hline Audrey Hepburn (Frode Grytten) novelle & 2001 & 1 \\
\hline Folkefest (Aleksander Kielland) novelle & 1880 & 1 \\
\hline Hjemkomsten (Kjell Askildsen) novelle & 1953 & 1 \\
\hline Kven sin kropp er dette (Rønnaug Kleiva) novelle & 1994 & 1 \\
\hline Jeg elsker deg (Kjetil Sangvik) novelle & 2003 & 1 \\
\hline Et hus av hender (Levi Henriksen) novelle & 2005 & 1 \\
\hline Hvitsymre i utslåtten (Hans E. Kinck) novelle & 1895 & 1 \\
\hline Tema (Bjørg Vik) novelle & 1968 & 1 \\
\hline Frå fyret (Gunhild Øyehaug) novelle & 2004 & 1 \\
\hline Riksvegen vestover (Kjartan Fløgstad) novelle & 1972 & 1 \\
\hline København (Katrine Marie Guldager) novellesamling & 2015 & 1 \\
\hline Den grønne kommoden (Selma Lønning Aarø) novelle & 1995 & 1 \\
\hline Korstroll (Hans E. Kinck) novelle & 1895 & 1 \\
\hline Kastemerket (Roy Jacobsen) novelle & 1994 & 1 \\
\hline Vinternoveller (Ingvild H. Rishøi) novellesamling & 2014 & 1 \\
\hline Livets røst (Knut Hamsun) novelle & 1903 & 1 \\
\hline \multicolumn{3}{|l|}{ Drama } \\
\hline Et dukkehjem (Henrik Ibsen) drama & 1879 & 47 \\
\hline Gengangere (Henrik Ibsen) drama & 1881 & 19 \\
\hline En folkefiende (Henrik Ibsen) drama & 1882 & 14 \\
\hline Peer Gynt (Henrik Ibsen) drama & 1867 & 12 \\
\hline Vildanden (Henrik Ibsen) drama & 1884 & 8 \\
\hline Erasmus Montanus (Ludvig Holberg) komedie & 1723 & 7 \\
\hline Nokon kjem til å komme (Jon Fosse) drama & 1996 & 5 \\
\hline Mens vi venter på Godot (Samuel Beckett) drama & 1948 & 5 \\
\hline En hanske (Bjørnstjerne Bjørnson) drama & 1883 & 3 \\
\hline As you like it (William Shakespeare) komedie & 1599 & 2 \\
\hline Hedda Gabler (Henrik Ibsen) drama & 1890 & 2 \\
\hline Ett drömspel (August Strindberg) drama & 1902 & 2 \\
\hline Vår ære og vår makt (Nordahl Grieg) drama & 1935 & 2 \\
\hline Dødsvariasjonar (Jon Fosse) drama & 2002 & 1 \\
\hline Fröken Julie (August Strindberg) tragedie & 1888 & 1 \\
\hline Jeppe på Berget (Ludvig Holberg) komedie & 1722 & 1 \\
\hline Ungen (Oskar Braaten) drama & 1911 & 1 \\
\hline Til lykke med dagen (Jens Bjørneboe) drama & 1965 & 1 \\
\hline Hamlet (William Shakespeare) tragedie & 1599-1601 & 1 \\
\hline Galileo Galilei (Berthold Brecht) drama & 1938 & 1 \\
\hline
\end{tabular}




\section{Vedlegg 4: Tabelloversikt over hele verk}

\begin{tabular}{|c|c|c|}
\hline Verk & Utgitt & Frekvens \\
\hline \multicolumn{3}{|l|}{ Romaner } \\
\hline Bli hvis du kan. Reis hvis du må (Helga Flatland) roman & 2010 & 11 \\
\hline Pan (Knut Hamsun) roman & 1894 & 10 \\
\hline Sult (Knut Hamsun) roman & 1890 & 9 \\
\hline Victoria (Knut Hamsun) roman & 1898 & 7 \\
\hline Sjur Gabriel (Amalie Skram) roman & 1887 & 7 \\
\hline Isslottet (Tarjei Vesaas) roman & 1963 & 7 \\
\hline Mengele Zoo (Gert Nygårdshaug) roman & 1989 & 5 \\
\hline Forrådt (Amalie Skram) roman & 1892 & 5 \\
\hline Fugletrubunalet (Agnes Ravatn) roman & 2013 & 4 \\
\hline Albertine (Christian Krogh) roman & 1886 & 4 \\
\hline Gift (Alexander Kielland) roman & 1883 & 3 \\
\hline Lillelord (Johan Borgen) roman & 1955 & 3 \\
\hline Trilogien (Jon Fosse) roman & 2014 & 2 \\
\hline Få meg på for faen (Olaug Nilssen) roman & 2005 & 2 \\
\hline Latours katalog (Nikolaj Frobenius) roman & 1996 & 2 \\
\hline Haiene (Jens Bjørneboe) roman & 1974 & 2 \\
\hline Kompani Orheim (Tore Renberg) roman & 2005 & 2 \\
\hline Fuglane (Tarjei Vesaas) roman & 1957 & 2 \\
\hline Naiv. Super (Erlend Loe) roman & 1996 & 2 \\
\hline Genanse og verdighet (Dag Solstad) roman & 1994 & 2 \\
\hline Alt inkludert (Marit Eikemo) roman & 2015 & 2 \\
\hline Gymnaslærer Pedersen (Dag Solstad) roman & 1982 & 1 \\
\hline Størst av alt (Malin Persson Giolito) roman & 2017 & 1 \\
\hline 1984 (George Orwell) roman & 1949 & 1 \\
\hline Hellemyrsfolket - én av dem (Amalie Skram) romansyklus & $1887-1898$ & 1 \\
\hline Vårnatt (Tarjei Vesaas) roman & 1954 & 1 \\
\hline Bikubesong (Frode Grytten) kollektivroman & 1999 & 1 \\
\hline Markens Grøde (Knut Hamsun) roman & 1917 & 1 \\
\hline Fred (Arne Garborg) roman & 1892 & 1 \\
\hline Garman \& Worse (Alexander Kielland) roman & 1880 & 1 \\
\hline Jo fortere jeg går, jo mindre er jeg (Kjersti Annesdatter Skomsvold) roman & 2009 & 1 \\
\hline Svermere (Knut Hamsun) roman & 1904 & 1 \\
\hline Amtmandens Døtre (Camilla Collet) roman & 1855 & 1 \\
\hline Kaniaw (Anja Breien) roman & 2006 & 1 \\
\hline
\end{tabular}




\section{S. Skaug og M. Blikstad-Balas}

(Fortsatte)

\begin{tabular}{|c|c|c|}
\hline Verk & Utgitt & Frekvens \\
\hline Mysterier (Knut Hamsun) roman & 1892 & 1 \\
\hline Egalias døtre (Gerd Brantenberg) roman & 2013 & 1 \\
\hline De dødes tjern (André Bjerke) roman & 1942 & 1 \\
\hline Tyl (Finn Tokvam og Halvor Folgerø) roman & 2007 & 1 \\
\hline Huset med den blinde glassveranda (Herbjørg Wassmo) roman & 1981 & 1 \\
\hline Skråninga (Carl Frode Tiller) roman & 2001 & 1 \\
\hline Doppler (Erlend Loe) roman & 2004 & 1 \\
\hline Jonas (Jens Bjørneboe) roman & 1955 & 1 \\
\hline Du er så lys (Tore Renberg) roman & 2016 & 1 \\
\hline Kjærlighet (Hanne Ørstavik) roman & 1997 & 1 \\
\hline Naustet (Jon Fosse) roman & 1989 & 1 \\
\hline Frankenstein (Mary Shelly) roman & 1818 & 1 \\
\hline Anne (Paal-Helge Haugen) roman & 1968 & 1 \\
\hline Alle utlendinger har lukka gardiner (Maria Navarro Skaranger) roman & 2015 & 1 \\
\hline Bipersonar (Carl Frode Tiller) roman & 2003 & 1 \\
\hline Til fyret (Viginia Woolf) roman & 1927 & 1 \\
\hline Mørkets hjerte (Joseph Conrad) roman & 1899 & 1 \\
\hline \multicolumn{3}{|l|}{ Noveller } \\
\hline Karens jul (Amalie Skram) novelle & 1885 & 13 \\
\hline Karen (Alexander Kielland) novelle & 1882 & 12 \\
\hline Faderen (Bjørnstjerne Bjørnson) novelle & 1860 & 4 \\
\hline En god samvittighet (Alexander Kielland) novelle & 1880 & 4 \\
\hline Luren (Maurits Hansen) novelle & 1819 & 3 \\
\hline Ringen (Knut Hamsun) novelle & 1897 & 2 \\
\hline Liket (Tor Jonsson) novelle & $1950 / 1952$ & 2 \\
\hline Ballstemning (Alexander Kielland) novelle & 1879 & 2 \\
\hline Naken (Tarjei Vesaas) novelle & 1998 & 2 \\
\hline Kruttrøyk (Torborg Nedreaas) novelle & 1945 & 1 \\
\hline Taustigen (Agnar Mykle) novelle & 1948 & 1 \\
\hline Liten knute (Gunhild Øyehaug) novelle & 2004 & 1 \\
\hline Mørke trær (Mikkel Bugge) novelle & 2014 & 1 \\
\hline Att døda ett barn (Stig Dagerman) novelle & 1948 & 1 \\
\hline Hjemme (Marie Aubert) novelle & 2016 & 1 \\
\hline Skolegutt (Laila Stien) novelle & 1979 & 1 \\
\hline Forvandlingen (Franz Kafka) novelle & 1915 & 1 \\
\hline Et spøkelse (Knut Hamsun) novelle & 1903 & 1 \\
\hline
\end{tabular}




\section{Hele tekster versus utdrag - hvilke tekster velger norsklererne?}

\begin{tabular}{|l|c|c|}
\hline Verk & Utgitt & Frekvens \\
\hline Madam Høiers leiefolk (Amalie Skram) novelle & 1882 & 1 \\
\hline Heimreisa (Oskar Braaten) novelle & 1913 & 1 \\
\hline Kremmerhuset (Oskar Braaten) novelle & 1930 & 1 \\
\hline En middag (Alexander Kielland) novelle & 1879 & 1 \\
\hline Stockholm (Bjarte Breiteig) novelle & 2000 & 1 \\
\hline Det røde gardin (Amalie Skram) novelle & 1899 & 1 \\
\hline Kunsten å myrde (Cora Sandel) novelle & 1935 & 1 \\
\hline Den store dagen (Reidun Elise Foldøy) novelle & 2008 & 1 \\
\hline Dansar du? (Frode Grytten) novelle & 1990 & 1 \\
\hline Mens hjula står (Oskar Braaten) novellesamling & 1916 & 1 \\
\hline Drift (Rolf Stenersen) novelle & 1931 & 1 \\
\hline Drama & & 1881 \\
\hline Gengangere (Henrik Ibsen) drama & 1882 & 26 \\
\hline En folkefiende (Henrik Ibsen) drama & 1879 & 25 \\
\hline Et dukkehjem (Henrik Ibsen) drama & 1884 & 20 \\
\hline Vildanden (Henrik Ibsen) drama & 1867 & 7 \\
\hline Peer Gynt (Henrik Ibsen) drama & 1890 & 6 \\
\hline Hedda Gabler (Henrik Ibsen) drama & 1996 & 5 \\
\hline Nokon kjem til å komme (Jon Fosse) drama & 1723 & 4 \\
\hline Erasmus Montanus (Ludvig Holberg) komedie & 1877 & 2 \\
\hline Samfundets støtter (Henrik Ibsen) drama & 1722 & 2 \\
\hline Antigone (Sofokles) tragedie & 1911 & 1 \\
\hline Jeppe på Bjerget (Ludvig Holberg) komedie & & 1 \\
\hline Vår ære og vår makt (Nordahl Grieg) drama & 1935 \\
\hline Ungen (Oskar Braaten) drama & 189 \\
\hline
\end{tabular}

